\title{
PROTESTA OBRERA Y SINDICALISMO EN LA INDUSTRIA TABAQUERA ESPAÑOLA (1887-1939)*
}

por

FERNANDO DEL REY REGUILLO

Universidad Complutense de Madrid

RESUMEN: El presente articulo ofrese una visión de conjunto sobre la bistoria del sindicalismo en la industria del tabaco en España. Una industria que por sus peculiares caracteristicas (su estrecba dependencia del Estado, la naturaleza monopolistica del sector, el peso abrumador de la mano de obra femenina o las tradiciones laborales forjadas) dio pie a unas prácticas movilizadoras que la singularizaron. El análisis se remonta a las primeras formulaciones de la protesta en forma de motín, para extenderse después a la etapa de consolidación de un modelo sindical sui generis. Erte modelo desembocó en una opción abiertamente nevolucionaria durante la Guerra Civil de 1936, que se frustró tras La victoria de la coalición de fuerzas antirrepublicanas en 1939.

Palabras clave: Sindicalismo. Industria tabaquera. Acción colectiva. España. Siglos XIX y XX.

ABSTRACT: This article offers an everview of the bistory of union activity in the Spanish tobacco industry. This industry, by virtue of its peculiar characteristics (its strict dependence on the state, its monopolistic nature, the crusbing weight of female labour) gave rise to some distinctive features of political mobilization. The analysis starts with the first formulations of protest in rioting, then expanding into a genuinely union-

- SIGLAS UTILIZADAS: ACAT, Actas del Consejo de Administración de la Compañía Arrendataria de Tabacos; ACAT/ZN, idem de la Zona Nacional; ACG, Actas del Comité de Gerencia; CAT, Compañía Arrendataria de Tabacos; DGTM, Dirección General del Timbre y del Monopolio; FTE, Federación Tabaquera Española (originariamente, Federación Nacional de Cigarreras y Tabaqueros). Siempre que en las notas a pie de página aparecen las siglas CAT seguidas de un año entre paréntesis se refiere a una Memoria anual de la Junta General de Accionistas. La cifra entre paréntesis se refiere al año de la memoria, no al año de edición necesariamente, aunque puedan coincidir. Si la sigla se refiere a ozra obra, se cira por CAT seguido del inicio del círulo de la obra en cuestión más el año de edición, y en su caso las páginas. 
ized model. The model led to an openly revolutionary movement in the Civil War of 1936, frustrated after the victory of the anti-Republican forces in 1939.

KEY wORDS: Trade Unionism. Tobacco industry. Collective action. Spain. XIX'th and XX Centuries.

Desde el punto de vista del conflicto y la práctica sindical, la industria del tabaco fue un microcosmos que tradujo bien las sacudidas que se dieron en la sociedad española durante el siglo XIX y primer tercio del XX. Pero también se ajustó a peculiaridades y desarrollos propios que tuvieron mucho que ver con las características de la industria tabaquera, su estrecha dependencia del Estado, la naturaleza monopolística del sector, las tradiciones de sus asalariados, su especial cultura movilizadora, la presencia abrumadora de mujeres en este sector productivo o la mitología creada durante décadas en torno a ellas - «las cigarreras»-, objeto de culto y de ensayos por parte de múltiples literatos, publicistas, curiosos y observadores extranjeros y nacionales, especialmente durante el siglo XIX. Aun así, la compartimentación cronológica del conflicto tabaquero corrió paralela a la evolución general de los movimientos sociales de la España de entonces, desde la época de la protesta tradicional en forma de motines (hasta la Primera Guerra Mundial), pasando por la aparición y desarrollo del sindicalismo de masas (1914-1936), hasta llegar al período de la Guerra Civil (1936-1939), con las experiencias de revolución y contrarrevolución que se dieron repectivamente en las dos zonas en que se dividió el territorio nacional. En este trabajo se ofrece una visión de síntesis de las líneas que articularon aquellos procesos, bajo la convicción de que la historia de los movimientos sindicales y de los trabajadores en España puede enriquecerse explorando universos sectoriales concretos. Al fin y al cabo, el mundo sindical de nuestro país estuvo muy condicionado hasta muy tarde por culturas de oficio, supervivientes tardías de sistemas gremiales formalmente periclitados desde los tiempos de la Revolución liberal ${ }^{1}$.

\section{MOTINES, LUDISMO Y CULTURA ANTICAPITALISTA (1887-1914)}

La constitución de la Compañía Arrendataria de Tabacos en 1887, como empresa privada gestora de un monopolio hasta ese momento controlado di-

\footnotetext{
1 Afortunadamente, en los últimos años han ido apareciendo varios estudios sobre la industria tabaquera, sus sistemas de trabajo, la historia de sus fábricas o las condiciones laborales de sus asalariados, antes y durance el periodo estudiado. Tales aspectos no se tratan aquí por falta de espacio, aunque resulten fundamentales y se hayan tenido en cuenta en el análisis de las luchas de cigarteras y tabaqueros. Cf. ValdÉs ChapULí (1990); Baena Luque (1993); Alonso AlVAREz (1994); Gálvez MuÑoz (1997); CANDEla SOTO (1993-1994), id. (1995) e id. (1997); RoMERO MASÍA (1997) y REY REGUILLO (1998). Una riquísima información de primera mano, en el anuario de SANTías (1894-1946).
} 
rectamente por el Estado, trajo aparejados importantes cambios en el régimen de trabajo de las fábricas del sector ${ }^{2}$. Entre otros factores, el maquinismo, la lenta pero constante amortización de personal o la paulatina reubicación de los recursos humanos con criterios empresariales, alteraron las tradiciones, costumbres e intereses que desde antiguo dibujaban la «economía moral» de las trabajadoras - y en menor medida trabajadores- de esta industria. Pues aquellos cambios no se produjeron sin acarrear tensiones y estallidos de protes$\mathrm{ta}^{3}$. Muy al contrario, desde el mismo instante en que la Arrendataria asumió las riendas de la producción y comercialización del tabaco en España, la contestación obrera fue una constante. No en vano desde atrás existía una tradición reivindicativa muy acentuada, y también muy singular en tanto que en esta industria como en ninguna otra las mujeres alcanzaron un enorme protagonismo. En otras formas conflictivas propias del siglo pasado y de principios del XX también se advirtió la presencia de mujeres (protestas contra las quintas, asonadas antifiscales, motines frente a la carestía de las subsistencias...), pero en las movilizaciones de la industria del tabaco su peso fue abrumador. En términos cuantitativos (que no cualitativos), los hombres que se destacaron en ellas fueron compañeros de viaje que se limitaron a reforzar unas acciones de protesta dirigidas, engrosadas y definidas mayoritariamente por las propias trabajadoras ${ }^{4}$.

2 Cuando en 1887 se constituyó la CAT, la industria del tabaco española - colonias al matgen- se sostenía sobre un entramado de 10 fábricas ubicadas en las siguientes ciudades: Sevilla (fundada en el siglo XVII), Cádiz (primer tercio del XVIII), Alicante (1801), Madrid (1808), La Coruña (1809), Valencia (1828), Santander (1834), Gijón (1837), Bilbao (1878) y San Sebastián (1878). A estos establecimientos se surnaron más tarde la fábrica de Logroño (1890) y la de Tarragona (1933). El Estado encargó a la CAT el objetivo de modernizar la industria tabaquera española. Ello condujo a la joven empresa a enfrentarse con una situación caracterizada, entre otros aspectos, por un enorme retraso técnico, una organización del personal precaria, una escasa división del trabajo, la masificación de las plantillas, una extendida insalubridad y el hacinamiento en los talleres. Ver CANDELA SOTO (1997), pp. 23-39 y 43. Los pormenores de la constitución de la CAT y del arrendamiento de 1887, en TORRES VILIANUEVA (1998). Acaba de aparecer una historia de la Compañía Arrendataria de Tabacos y de Tabacalera (la empresa que le tomó el relevo después de la Guerra Civil de 1936) que aporta una visión global (económica, empresarial, laboral, etc.) sobre el desarrollo de esca industria en España hasta la actualidad. Ver COMín y MARTín ACEÑN (1999).

3 GALVEZ MUÑOZ (1997), p. 75 ve en las protestas de las cigarreras a finales del XIX una lucha, concretamente, por mantener el modelo de economía doméscica a través del empleo hereditario y un compromiso laboral flexible que les permitiera compacibilizar su trabajo casero con el fabril. Pretensión incompatible con la estrategia de racionalización capicalista que asumió la CAT. Para los escallidos de protesta del período anterior a 1887 , además de los crabajos citados en la nota 1 , cf. MORANGe (1980) y V ALLEJo FERNÁNDEZ (1986).

4 En el momento de su constitución, la CAT recibió del Estado 31.384 operarias. Trece años más tarde el volumen total de personal obrero se había reducido en más del 25 por 100 (en concreto, 22.547 trabajadoras). En 1910 la cifra de cigarreras había descendido a 17.668 , y en 1930 a 13.198 (CANDELA SOTO (1997), pp. 45 y 50 . Si a finales del XIX sólo un 1 por 100 del personal eran hombres, ese porcentaje fue creciendo paulatinamente al hilo del proceso de mecanización, 
A la luz de las transformaciones que generaron los criterios puramente empresariales de la CAT, las cigarreras tradicionales - trabajadoras manuales, artesanas identificadas con el producto de su trabajo- fueron cediendo el paso a las obreras fabriles vinculadas a la máquina, eslabón anónimo y despersonalizado de una industria paulatinamente mecanizada. Pronto llegarían los tiempos de los "obreros conscientes", de los obreros comprometidos en las luchas sociales, en la constitución de sindicatos y en el lanzamiento de huelgas que pusieron en aprieto a la empresa. Pero en esta industria se contó con un capital de prácticas reivindicativas acumulado previamente. Durante todo el siglo XIX la mano de obra de las fábricas de tabacos había pesado mucho en la conflictividad social del país. En su particular cultura movilizadora se configuró un elemento esencial que, después, cuando la gestión del monopolio pasó a manos privadas, siguió guiando las luchas obreras: ese elemento fue la conciencia de ser trabajadoras del Estado, trabajadoras de un monopolio público que, por su mismo carácter, venía generando importantes beneficios. En el XIX, las cigarreras fueron plenamente conscientes de ese rasgo distintivo que las colocaba en posiciones de privilegio con relación a la mayor parte de las otras industrias. Eran trabajadoras del Estado, por un lado, y trabajadoras de una empresa rentable dada su naturaleza monopolística, por otro; no asalariadas de empresarios privados, y eso les confería un enorme potencial para plantear exigencias, un espacio privilegiado para la presión reivindicativa del que no gozaban los trabajadores - la inmensa mayoría - de la empresa privada. Pues el planteamiento de una movilización se convertía de inmediato en un problema de orden públi$\mathrm{co}$, ya que el punto de mira, el centro donde confluían los gritos de protesta era el mismo Estado, y como representante del mismo el gobierno de turno. Eso generaba al instante un clima desestabilizador cuyas imprevisibles consecuencias siempre temieron las autoridades. Máxime por conllevar esta industria unas concentraciones de mano de obra verdaderamente insólitas en su tiempo, hasta el punto de que las fábricas de tabacos, allí donde se ubicaron, fueron con mucha diferencia casi siempre las mayores empresas por número de empleados del entorno urbano inmediato. Cabe añadir el dato nada irrelevante de que el tabaco era un producto consumido masivamente por todas las clases sociales, razón por la cual su desabastecimiento provocaba un gravísimo malestar social. Esta dimensión también influía de manera importante para que las trabajadoras del sector ejercieran su capacidad reivindicativa.

En parte porque se lo ganaron a pulso, en parte por la fuerza de la propia recreación literaria y artística de que fueron objeto por escritores, músicos y observadores de sus andanzas, es el caso que en torno a las cigarreras se forjó

\footnotetext{
singularmente a partir de los años veinte del siglo siguiente (GÁLVEZ MUÑoz (1997), p. 76 y passim). Del mismo modo, en coincidencia con el desarrollo del sindicalismo a partir de la Primera Guerra Mundial, también se reforzó su liderazgo en términos proporcionalmente mucho más acusados.
} 
todo un mito que, sin duda, ellas mismas, los gobernantes y después la propia Compañía Arrendataria de Tabacos, acabaron interiorizando. Cada vez que se abrían las puertas a su cólera, cada vez que se levantaban ante lo que consideraban una injusticia por parte de los responsables de la industria, la prensa, el parlamento y los representantes políticos se hacían eco de los acontecimientos. La sociedad en su conjunto se conmovía ante el espectáculo de ver a miles de mujeres - trabajadoras, mujeres pobres del arrabal, madres de abundante prole muchas de ellas- ocupando la calle con sus gritos contra la ignominia y la explotación de que eran objeto. $\mathrm{Y}$ el gobierno, sin intermediarios hasta que se constituyó la CAT, aparecía como el directo responsable de esa situación. En muchos casos, la opinión tendió siempre a apoyar las movilizaciones de las cigarreras - autoridades locales incluidas_, dada la importancia económica de las fábricas de tabaco en sus respectivas ciudades 5 .

Resulta fácil, por todo ello, aprehender los efectos desestabilizadores que una movilización de cigarreras podía alcanzar. Ellas eran conscientes de su fuerza y a la primera de cambio la esgrimían. Con tino y agudeza lo captó el cronista en 1886 , al calor de una de aquellas movilizaciones, de la fábrica de Madrid en concreto, que por razones obvias de ubicación y cercanía al poder eran las que más temían las autoridades: «Un conflicto en la fábrica de tabacos es un asunto más grave de lo que parece. Son más de cuatro mil mujeres, que dan un contingente, al menos, de ocho mil hombres, padres e hijos, hermanos, maridos y amantes de la llamada gente del bronce, hombres a los que si les faltara valor, las mujeres les escupirían a la cara». Unos años después, en 1898, con la CAT ya en funcionamiento, La Ilustración Española y Americana nos devuelve la imagen y subraya la fuerza del mito: «Las cigarreras de Madrid constituyen un poder ante el cual ceden el estado de sitio, la misma guardia civil, la Iglesia y el Gobiernom. Nadie podía garantizar, además, que la meticulosa jerarquización en categorías laborales que presidía la organización de las fábricas - pensada para neutralizar los potenciales estallidos de protesta y los desórdenes- fuera una garantía eficaz ante la cólera de las cigarreras: «Frente a los nuevos impulsos, nada vale la autoridad de las amas de rancho, de las maestras de taller, de las porteras; con frecuencia, ellas mismas se solidarizan con las obreras a sus órdenes». La red de solidaridades colectivas que generaba la propia fábrica y la tradición combativa alimentada durante generaciones de cigarreras echaba por tierra la fuerza disuasoria de la autoridad y la jerarquía. Una y otra vez se iba a poner de manifiesto, aunque los nuevos gestores no se quedaron con los brazos cruzados, sino que, conscientes del avispero que tenían ahora a su cargo, se aprestaron a idear mecanismos y políticas dirigidas a conjurar los peligros y el virus de la sedición. Porque como peligrosas sediciones se conceptuaron siempre las prácticas reivindicativas de las cigarreras por parte de la empresa. Verdaderamente, se puede afirmar que la dirección de la Arrenda-

5 En el caso sevillano, GAlvez MUÑoz (1997) insiste en esta dimensión de la procesca. 
taria nunca vio con buenos ojos la aparición de un sindicalismo independiente entre sus asalariados. Desde la estricta lógica de la empresa y a partir del discurso de aquel sindicalismo - un discurso virulentamente anticapitalista desde el principio de esta historia hasta el final-, no les faltaron razones a los gestores de la CAT pata alimentar sus temores ${ }^{6}$.

Los conflictos que sostuvieron las cigarteras en las primeras décadas de historia de la Arrendataria no se diferenciaron de los que se venían produciendo con anterioridad a la constitución de la empresa. Todos los rasgos de las formas tradicionales de protesta social nos los encontramos en las fábricas de tabacos hasta la coyuntura de 1914: insurreccionalismo espontáneo, virulencia y fugacidad en el estallido, carencia de un liderazgo claro y preestablecido, carencia también de programa, descoordinación, existencia de un motivo inmediato como catalizador de un descontento latente desde tiempo atrás, instinto nivelador en la multitud encolerizada... No es cuestión de hacer una descripción detallada de todos los conflictos que recorren las casi tres décadas que transcurren hasta el comienzo de la Primera Guerra Mundial. Sólo se aludirá a los principales casos, bien escogidos para diseccionar las líneas de fuerza que presidieron esta primera secuencia conflictiva, clara prolongación en el tiempo de la protesta tradicional?.

Y nada mejor que irse a los orígenes, cuando la Compañía Arrendataria echó a andar. Nada mejor porque desde ese mismo instante se definieron las respuestas de la empresa y las motivaciones de la movilización tabaquera: su carácter preventivo frente a unos nuevos gestores que despertaban recelos; la reivindicación del mantenimiento de la dependencia directa del Estado; el miedo de las cigarreras a los costes de la racionalización productiva que no se recató en anunciar la nueva Compañía (amortización del personal, mecanización, implantación de nuevas labores más acordes con los gustos del mercado...); el poso ludita y contrario a la modernización tecnológica en la conciencia obrera; la obsesión en la dirección de la empresa por mantener el principio de autoridad y la disciplina, al compás de la consideración de todo conflicto como un mero problema de orden público; su apelación constante a las fuerzas de seguridad del Estado; el recurso al cierre como hecho consumado para doblegar el motín o el tumulto desestabilizador... En el mismo año de 1887 ya se le plan-

6 Las citas entrecomilladas, en PÉrez VIDAL, J. (1959), p. 291. El cronista es Rodríguez Solis. La última cita del párrafo es del propio Pérez Vidal. Gálvez MuNoz (1997) sostiene la resis, para la fábrica de Sevilla, de que la CAT asumió la política amortizadora del personal de forma lenta con el fin de que no resultara traumática. Ciertamente, la desconfianza obrera hacia las máquinas retrasó la mecanización de las fábricas (por ejemplo, la de Madrid, como cuenta CANDELA SOTO (1997)). Con todo, esa circunstancia no se dio con la misma intensidad en todos los establecimientos, de modo que a principios de siglo varios de ellos se encontraban en pleno desarrollo mecánico.

7 Las características básicas de la conflictividad en el cruce de siglos pueden encontrarse en dos trabajos que ofrecen un estado de la cuestión: Pérez Ledesma (1990) y Pérez Garzón y ReY REGUILLO (1994). 
teó un conflicto serio a la Compañía. Ocurrió en la fábrica de Madrid, una de las más combativas: «De antiguo viene lamentándose la Administración de las condiciones de la fábrica de Madrid y de los vicios y abusos que en ella se han cometido y que teniendo hondas raíces y una larga tradición no es fácil extirparlos por completo. Hay en el personal obrero de este Establecimiento un espíritu de indisciplina que lucha casi siempre con las conveniencias e intereses de la Renta». El testimonio apunta algunos de los condicionantes: el estado del edificio y el excesivo número de personal que trabajaba en el mismo, «que impide la necesaria separación de talleres" 8 .

Pero fue la introducción de nuevas labores y la pretensión de racionalizar la producción disminuyendo costes la causa que generó más descontentos. La dirección se hallaba persuadida de que convenía una reforma «encaminada a simplificar las confecciones, a darles más flexibilidad, a lograr mayores economías (...) y a conseguir (...) un tendimiento líquido mayor de cada una de ellas». Con este objeto se crearon las nuevas labores de cigartillos «superiores", «finos» y «entrefinos». Las reformas «encaminadas a ello promovieron la perturbación ocurrida en la Fábrica de Madrid en el mes de Octubre de 1887». Que no impidió, sin embargo, que la Compañía cejara en su empeño, aun cuando reconocía los peligros y dificultades que entrañaba su política: «sobre todo si su realización depende en parte de un personal obrero, en el cual ha venido dominando el espíritu de indisciplina. No es fácil imaginarse, cuando se ven expuestas a la venta nuevas labores, todos los inconvenientes que hubo necesidad de vencer». $Y$ es que introducir nuevas labores exigía nuevos aprendizajes, la reacomodación del personal y muchas veces la disminución de las ganancias de éste, al ser un trabajo que se cobraba en función de lo producido. La falta de adiestramiento en una determinada labor suponía de hecho el recorte de los beneficios para el trabajador, al menos en tanto adquiría la habilidad suficiente para equiparar la rentabilidad de la nueva labor a la de la anterior ${ }^{9}$.

Sin embargo, fue al siguiente año, en 1888, cuando se planteaton los conflictos más graves, que alcanzaron la forma de «injustificados motines" -al decir de los responsables de la Compañía- y tuvieron como escenario las fábricas de Alicante y Cádiz. Con el precedente de Madrid, al introducir nuevas labores la empresa se apresuró aquí a elevar los premios de las confecciones, para quitar todo posible pretexto a la perturbación de las fábricas. Pero esta estrategia no surtió efecto, porque en realidad lo que se estaba cuestionando era la propia viabilidad de la Compañía como gestora de la industria del tabaco, de acuerdo con la impresión que se tenía en la dirección: «se ponía en discusión la fuerza y la autoridad de la Compañía e iba por tanto a decidirse si alcanzaría o perdería por el contrario el necesario prestigio para dar a aquellos

- SeCRETARÍA Del CONSEjo dE ADMINISTRACIÓN (1888), pp. 33-34.

9 Todas las citas, en CAT (1889), pp. 14-15 y 25. 
establecimientos su carácter industrial» ${ }^{10}$. Cuando la Compañía acometió la creación de nuevas labores y la reorganización general de la industria del tabaco fue consciente de que las alteraciones podían producirse. Convencida de ello intentó evitar los motivos que pudieran llevar a promover motines y perturbaciones. Ahora bien, una vez que estos se produjeron se decidió a actuar contundentemente. Primero, en Alicante; después, en Cádiz. En la primera ciudad el motín estalió el 28 de agosto con la reivindicación de expulsar a una maestra. La gravedad de los acontecimientos condujo a la rápida intervención del gobernador, el alcalde, la Guardia Civil y los carabineros. El primero ordenó el cierre de la fábrica, decisión que la dirección de la empresa en Madrid, no dispuesta a ninguna transacción "ni debilidades", vio con buenos ojos. El ministro de Hacienda, puntualmente informado, se mostró conforme con las resoluciones tomadas. La sorpresa vino cuando a las pocas horas llegó a Madrid la noticia de que el jefe de la fábrica de Alicante y el gobernador habían decidido abrir el establecimiento al día siguiente. Eso generó gran contrariedad en los responsables de la CAT, que entraron en contacto con el ministro de la Gobernación para que obligase al gobernador de Alicante a dar marcha atrás. Ellos mismos hicieron lo propio con el jefe de la fábrica citado. Incluso comunicaron oficialmente que estaban dispuestos a reducir en un 25 por 100 el personal obrero, medida que no se había aplicado hasta ese momento, pero que el contrato de la Compañía con el Estado permitía. El problema no era el motín de Alicante en sí, sino el precedente que se sentaba ante todas las fábricas, pues de triunfar aquél se colocaba a la Compañía en una situación muy difícil para proseguir sus reformas y para su propia supervivencia ${ }^{11}$.

Puestos de acuerdo el ministro de Hacienda, el de Gobernación y los responsables de la Compañía, se reafirmaron en su decisión de mantener cerrada la fábrica. El asunto se llevó incluso al Consejo de Ministros y se habló de clausurarla definitivamente a principios de septiembre. Mientras tanto, el gobernador civil de Alicante manifestó que no se hacía responsable del orden público si se decretaba el cierre. Lo cual no arredró a Amós Salvador, que como subdirector de la Compañía era el que tomaba sobre la marcha las decisiones más perentorias, sabedor de que lo que se jugaban era mucho más que la derrota o victoria en un conflicto concreto. Gracias a las gestiones practicadas y al apoyo resuelto del gobierno y del ministro de Hacienda, se ordenó al fin el cierre de la fábrica, «con lo cual quedó a salvo el prestigio de la Compañía y su autoridad». Los «efectos saludables" que deseaban los responsables de la empresa fueron inmediatos. Una comisión presidida por el alcalde de Alicante y compuesta por representantes de aquella ciudad solicitó una conferencia con Amós Salvador: «para suplicarme que no se convirtiera en definitiva la medida de cierre» y que procurase acelerar la apertura, bajo el compromiso de prestar su apoyo a la

10 SECRETARÍa del CONSEjo de ADMINISTRACjÓN (1888), [pp. 48-49].

i SECRETARÍA DEL CONSEjO DE ADMINISTRACIÓN (1888), [p. 54 y passim]. 
Compañía para evitar que se reprodujeran «hechos tan lamentables como los acaecidos en aquella fábrica». La comisión asumió, además, la aceptación de las nuevas labores e incluso la supresión del 25 por 100 del personal obrero, si bien rogó que en ese momento no se llevase a la práctica. El 17 de septiembre se reanudaron los trabajos. El 18 el jefe de la fábrica comunicó que, con motivo del recibimiento que las operarias iban a hacer a la comisión a su vuelta a la ciudad, «la situación presentaba para la Administración y empleados muchísimo peor aspecto que el día del motín». Peto la Compañía no cedió un ápice, ya que se trataba de inaugurar una nueva etapa donde los errores del pasado - las situaciones de indisciplina incluidas- no se volvieran a repetir. El cierre patronal, en efecto, se mostró efectivo, de modo que la primera batalla la acabó ganando la Compañía. No iba a ser la última, pero con ella se había inaugurado una línea de actuación - basada en la «disciplina», «la energía» y el «vigor»- que de hecho cerraba una época, la época de las contemporizaciones del Estado frente a las movilizaciones de las cigarreras. Implícitamente, la constitución de la CAT, bajo los argumentos genéricos de mejorar la producción, los rendimientos y la gestión del monopolio, busc6 encuadrar con criterios capitalistas a una masa laboral acostumbrada, si no a campar por sus respetos, sí a imponer muchas veces sus condiciones a un Estado al que, hábilmente, se lograba acorralar con relativa facilidad. La privatización de la gestión del monopolio consiguió por primera vez que se tambaleara el mito de las cigarreras irreductibles ${ }^{12}$.

Los conflictos que se fueron produciendo después parecieron apuntar en la misma dirección que en el conflicto de Alicante. Los sucesos de la fábrica de Cádiz, que tuvieron lugar también en septiembre (el día 4 se iniciaron), no alcanzaron tanta importancia, si bien la secuencia fue muy parecida. Surgió el alboroto en demanda de mayores premios de elaboración; se produjeron destrozos en la fábrica; intervinieron las fuerzas del orden; se desalojó el recinto fabril; el gobernador ordenó la apertura al día siguiente, autorizando la confección de labores antiguas y suprimiendo las modernas; pero la Compañía se mantuvo firme en el cierre contando con el apoyo del gobierno. A continuación se implicaron el Ayuntamiento y la Diputación de Cádiz en demanda de la apertura del establecimiento. Al final se abrió, el día 17, una vez que las autoridades locales se comprometieron a preservar el orden y una vez que las instigadoras resultaron castigadas, con el consiguiente robustecimiento de la autoridad de la Compañía, que contó con el incondicional apoyo del Estado para continuar implantando las reformas ${ }^{13}$. Las resistencias por parte de las cigarreras continuaron en pie largo tiempo, y una tras otras fueron perdiendo todas sus luchas, aunque, eso sí, con fuertes costes para la empresa: se arrancaron concesiones y las derrotas nunca tuvieron el significado de una completa capi-

12 Secretaría del CONSEjo de Administración (1888), [p. 55-59] y CAT (1890), p. 10.

13 SECRETARÍA DEL CONSEJo de AdMINISTRACión (1888), [pp. 60-64]. 
tulación. Y lo que es más importante: esas derrotas abrieron las puertas a institucionalizar la movilización obrera, que hasta entonces siempre había sido improvisada. Desarrollar una organización más compleja y ensayar nuevas formas de acción, más eficaces y contundentes en respuesta a unos gestores cuya legitimidad como directores del monopolio nunca se acabó de aceptar, tal fue a partir de ahora el objetivo.

Durante los años noventa y, luego, en la primera década del siglo $\mathrm{XX}$ asistimos a conflictos de parecidas características. Es de reseñar, por ejemplo, que la celebración del $1^{\circ}$ de mayo desde 1890 generó solidaridades en las fábricas de tabacos. A veces, también, la conflictividad general de una ciudad arrastró en la vorágine a las cigarreras, pero todavía no era una época en que proliferaran las huelgas generales, aunque pudiera darse algún atisbo en ese sentido. En 1891, la caída de un cristal que hirió a varias operarias en la fábrica de Madrid provocó nuevos disturbios que desembocaron en un paro de protesta. En el mismo, los ataques se dirigieron directamente al propio administrador de la CAT. El 23 de enero de 1896 se produjo un motín de gran violencia en la fábrica de Sevilla, en respuesta a la exigencia de más calidad en las labores forzada por los responsables del establecimiento. Como en otras ocasiones, el conflicto, que no se agotó hasta pasados diez días, provocó la intervención del Ejército. Años después, con motivo de los acontecimientos del 98, la Compañía temió que se reprodujeran los estallidos en las distintas dependencias fabriles; no sólo quiso evitar a todo trance «el riesgo de una modificación radical y brusca en las labores, que pudiera afectar a las ventas, sino que habían de impedir cualquiera paralización en los trabajos de las fábricas, origen acaso de graves perturbaciones de orden público en días como aquellos de suprema angustia (...). Por fortuna las providencias adoptadas por éste [el Consejo], reforzando los repuestos y adquiriendo en cantidad bastante tabaco húngaro y del Brasil (...) dieron los resultados apetecidos, lográndose que las confecciones se realizasen con normalidad suficiente» ${ }^{14}$.

A lo largo de la primera década del nuevo siglo también menudearon los conflictos en las fábricas de tabacos. En la primavera de 1902 las cigarreras madrileñas acordaron celebrar todos los dorningos mítines para protestar contra la crisis de subsistencias. Unos meses después, se declararon en huelga ocupando los talleres de las buhardillas de la fábrica por no poder resistir el calor asfixiante existente allí. En 1903 plantearon de nuevo una huelga como rechazo de la mala calidad del tabaco. En enero de 1904 «hubo un pequeño movimiento de rebeldía en la Fábrica de Gijón, y otro en mayo [de 1903] en la de Santander por resistencias al cumplimiento de las órdenes dictadas para la ejecu-

14 CAT (1899), pp. 5-6. También, CANDELA SoTo (1993-1994), p. 109. Lo de Sevilla, en BAENA LUQUE (1993), pp. 116-12l y GÁLVEZ MUÑoz (1997), pp. 78-81. Las labores se veían dificultadas y la calidad se resentia - mermando la ganancia de las operarias, que cobraban en razón de la cantidad producida - porque la mareria prima y el papel que proporcionaba la empresa a las trabajadocas venían en muy malas condiciones. 
ción de las consignaciones del mes. Ambos fueron aquietados rápidamente, manteniéndose, cual corresponde, el principio de autoridad». En 1905, otra vez en Madrid, se fue a la huelga con la exigencia de una subida salarial. En abril de 1906, las cigarreras gaditanas demandaron mejor calidad en el papel para liar los cigarrillos. En octubre del mismo año, las madrileñas reiteraron sus protestas ante el temor de que se sustituyeran operarias por máquinas y bajo la sospecha, además, de que en algunos conventos se hacían labores de tabacos por encargo expreso de la empresa. En enero de 1907, la fábrica de Alicante se cerró un día por un motín que tuvo lugar en la ciudad a raíz del intento por parte del alcalde de gravar la venta ambulante ${ }^{15}$.

Por último, en febrero de 1908, otra vez en la fábrica de Alicante, se asistió a otro caso tardío de revuelta ludita contra los intentos de la Compañía por introducir nueva maquinaria. La agitación que se organizó terminó como el rosario de la aurora, pues aparte de las obreras miles de personas se arremolinaron en los alrededores del establecimiento haciendo causa común con ellas. Tanto es así que se requirió la intervención de la Guardia Civil, los carabineros, la guardia municipal y los agentes de seguridad. Las máquinas fueron en su totalidad destruidas y miles de personas asaltaron, además, uno de los almacenes, atropellando a la fuerza que lo protegía. Pese a que la Compañía iba aplicando la mecanización e introduciendo las máquinas «con natural moderación y exquisita prudencia" para no exaltar los ánimos del personal obrero, no deja de sorprender una manifestación de ludismo tan radical todavía en esas fechas. La Compañía atribuyó esta reacción al hecho de que las cigarretas de Alicante habían sido "mal aconsejadas", ya que, paralelamente, se introdujeron muchas máquinas nuevas sin el menor contratiempo en las fábricas de Logroño, Valencia, La Coruña y Sevilla. La Compañía procuró siempre actuar con extrema cautela en este asunto. De hecho, la introducción de máquinas a menudo no llevó aparejada la reducción del empleo ${ }^{16}$.

\section{LA ECLOSIÓN SINDICAL EN LA INDUSTRIA DEL TABACO (1914-1923)}

A partir de la coyuntura abierta por la Primera Guerra Mundial, diversos factores se conjugaron propiciando una mutación de la protesta social en relación a las tradiciones heredadas: el crecimiento económico acelerado y especulativo, la inflación, el proceso de expansión urbana fruto de un inaudito aluvión

13 Cf. Valdés Chápuli (1990), p. 97, Baena LuQue (1993), p. 123 y Candela Soto (1997), pp. 172-173. Las comillas, en CAT (1904), p. 14.

16 VALDÉs CHÁPULI (1990), p. 98, CAT (1908), pp. 6-8 y CAT (1909), pp. 9-10. En 1909, la introducción de máquinas supuso en la fábrica de Sevilla la contratación de 253 aprendizas, después de dos décadas ininterrumpidas amortizando personal (GÁLVEZ MUÑoz (1997), pp. 86-87), Del mismo modo, en 1910 la introducción de ocho tiruleras en la fábrica de Madrid conllevó la admisión de otras doscientas (CAT (1910), pp. 12-13 y CAT (1911), p. 9). 
migratorio de origen rural, la crisis política del régimen, el impacto de la revolución rusa y el propio crecimiento de las organizaciones obreras consecuencia de todas esas causas. Nuevas pautas organizativas y nuevas fórmulas conflictivas (retroceso del motín tradicional, multiplicación de las huelgas) configuraron así una etapa singular en la historia de los movimientos sociales españo$\operatorname{les}^{17}$. La industria del tabaco no pudo sustraerse a los acontecimientos. Sus trabajadores también se vieron sacudidos e implicados por la eclosión sindical, también se movilizaron como nunca lo habían hecho y también ensayaron las nuevas formas reivindicativas para presionar a la empresa en pos de sus objetivos. De hecho, la crisis bélica inauguró en el sector el proceso de organización sindical, hasta entonces prácticamente inexistente.

Si bien no resulta fácil realizar el seguimiento de la formación del asociacionismo obrero en las fábricas tabaqueras - las fuentes son dispersas y escasas--, todos los testimonios y estudios disponibles apuntan a la segunda década de este siglo como el momento de arranque de los primeros sindicatos modernos en esta industria, que en su mayoría lo fueron inicialmente de inspiración socialista. En 1910, al menos, ya existía en La Coruña una denominada Asociación de Cigarreras, que seguramente fue el antecedente de la Unión Tabacalera constituida en la fábrica de esa misma ciudad en 1915. Entre los primeros sindicatos de cigarreras es muy posible que fuera éste, si atendemos a su protagonismo inmediato, el más relevante. Porque de Unión Tabacalera, es decir, de las cigarreras coruñesas, surgió la iniciativa de crear una gran organización sindical a escala nacional. No obstante, a principios de la Gran Guerra ya se tuvo noticia de la existencia de alguna entidad similar a la Unión en otras fábricas: en Alicante, en concreto, se formó una agrupación de tipo reivindicativo entre las cigarreras en 1916 , que respondió al nombre de «La Feminista» ${ }^{18}$.

En el año 1917, año crítico para la vida española por tantos conceptos, se tiene constancia de la existencia de ciertas tensiones en las fábricas de tabacos, sin duda relacionadas con la efervescencia asociativa que los sindicatos venían alentando para organizar a las cigarreras. El 11 de julio, por ejemplo, a consecuencia de un incidente entre dos operarias ocurrido en la fábrica de Madrid, se produjo «en la misma alguna agitación que se temió pudiera adquirir cierta gravedadm. Durante esos meses proliferaron los informes negativos sobre los niveles de producción de varios establecimientos, el de Madrid incluido. Generalmente, los bajos rendimientos solían coincidir con las fábricas donde se cocía el descontento y la agitación. La Compañía se vio obligada a realizar una política de cambios y traslados en la dirección de las más conflictivas a fin de atemperar los ánimos (además de la fábrica de la capital, las de La Coruña, Alicante, Santander y Cádiz). La famosa huelga general de agosto de 1917

17 Pérez Garzón y Rey Regullio (1994), pp. 290-297.

18 Cf. para estos primeros atisbos asociativos: CAPEL MARTíneZ (1982), VAldés ChápULl (1990), p. 88 p. 254 ss., CANDELA SOTO (1993-94), p. 109, e id. (1997), p. 174, y ROMERO MASIA (1997), pp. 83-108. 
respondió a motivaciones estrictamente políticas, pero sus consecuencias también repercutieron, al menos indirectamente, en las fábricas de tabacos. De hecho, la dirección de la Compañía no se mantuvo impasible. El mismo día 23 de aquel mes se acordó contribuir con 25.000 pesetas a la suscripción abierta en favor de las fuerzas de seguridad que estaban interviniendo para reprimir a los revoltosos. Con este gesto, la Arrendataria no hacía sino exactamente lo mismo que otras grandes empresas, organizaciones patronales, «fuerzas vivas» y particulares en su apoyo de un orden social que se estimó seriamente «perturbado" y amenazado. No era la primera vez, ni iba a ser la última. El respaldo, tanto moral como material, a las autoridades políticas y militares en momentos de inestabilidad social - que nunca dejaron de agradecer- formaba parte de toda una tradición cuyas raíces se perdían en el siglo XIX ${ }^{19}$.

El único lugar de donde se tienen referencias sobre la intervención de las fuerzas de seguridad para velar por los intereses de la Arrendataria fue la fábrica de La Coruña. El regimiento de artillería de aquella plaza contribuyó a su protección, una vez que a efectos preventivos se decidió su cierre. La Guardia Civil también desplegó «interés y celon en la vigilancia y custodia del referido establecimiento. Los responsables de la Compañía se desvivieron en mostrar su agradecimiento a esas fuerzas y contribuyeron a la campaña local de donativos puesta en marcha en su provecho. El contrapunto a esta actitud de apoyo a las fuerzas de seguridad del Estado, que habían actuado en defensa del orden establecido frente a la huelga general revolucionaria, vino dado unos meses después. En diciembre, la dirección de la Compañía recibió una carta-circular suscrita por una denominada comisión gestora de los obreros despedidos — «seleccionados", se decía- por la Compañía de Ferrocarriles del Norte, con motivo de la huelga de agosto. En esa carta se solicitaba a la Arrendataria una ayuda para remediar la precaria situación de esos trabajadores represaliados. La dirección de la industria tabaquera se limitó a contestar de forma lacónica (en contraste con el tono eufórico demostrado escasos meses atrás cuando de apoyar al Ejército y a la Guardia Civil se trató): «el Consejo desestimó esta petición por no disponer la Compañía de crédito para poder atenderla ${ }^{20}$.

En la particular dinámica conflictiva y de impulso sindical de las fábricas de tabacos, sin embargo, no fue tanto 1917 como 1918 el año que representó un

19 Los cambios en la dirección de las fábricas, en ACAT, 12-VII-1917, 2-VIII-1917 y 4-X. 1917. CAT (1918), p. 16 y ACAT, 23 y 30-VIHI-1917, para las 25.000 pesecas. Para la cultura del donatito a las fuerzas de seguridad del Estado can arraigada entre las "fuerzas vivas", véase REY REGUILIO (1992).

20 ACAT, 27-XII-1917. Los otros donativos, en ACAT, 30-VIII-1917, 20-IX-1917 y 7-X1917. El 30 de agosto se aprobó uno de 250 peseras con descino al regimienro de artillería; el 20 de sepriembre se envió una comunicación al direccor general de la Guardia Civil expresándole el agradecimiento de la Compañía por su actuación en defensa de la fábrica de tabacos; el 7 de octubre se acordó enviar un donativo de 100 pesetas para una función de teatro en beneficio del Ejército, organizada por el alcalde de la ciudad gallega. Cf. también ROMERo MAsía (2000), pp. 124-178. 
punto de inflexión verdaderamente significativo. Porque fue ese año cuando nació la Federación Tabaquera Española (FTE), y fue ese año también cuando se inició una espiral huelguística y reivindicativa que sólo mostró síntomas de agotamiento a finales de 1920. Al hacer balance de estos años en sus memorias anuales, la Compañía se refiere a ellos como un período "estremadamente difícil: que la liquidación de la cruenta guerra padecida durante cerca de cinco años, con el encarecimiento general de la vida que ha traído, los trastornos sociales, que son su secuela, y la multitud de problemas de varios órdenes que plantea, lo embaraza y lo perturba todo». Desde su análisis dos fueron los "elementos de perturbación» que, en ese contexto ocasionado por la guerra, generaron la dinámica desestabilizadora: «el acarreado por la agitación social llevada a las Fábricas de Tabacos y la implantación de la jornada de ocho horas, disminuyéndose la producción». Ciertamente, fue a partir de 1918 cuando se intentó coordinar las movilizaciones de las trabajadoras del tabaco, hasta entonces carentes de conexión suficiente y atomizadas desde el punto de vista asociativo ${ }^{21}$.

Parece ser que el movimiento partió, como se ha indicado antes, de la fábrica de La Coruña, donde apareció también un personaje que se iba a convertir en el primer gran líder del sindicalismo tabaquero español: Severino Chacón, militante socialista, presidente de la Unión Tabacalera coruñesa y, sin duda, la figura más importante en toda la historia del asociacionismo tabaquero. Ya desde el verano de 1918, o incluso antes, se fue vislumbrando el «estado de agitación y espíritu de indisciplina del personal obrero» en muchas fábricas, como consecuencia "de la propaganda incesante» que venían realizando los sindicalistas entre sus trabajadores, con vistas a asociarlos en organizaciones fuertes: las fábricas de Cádiz, Gijón, La Coruña y Sevilla se situaron de inmediato en la vanguardia de ese movimiento, produciendo la intranquilidad de las autoridades políticas y militares, así como gran preocupación entre los gestores de la Arrendataria. La fábrica de Sevilla llegó a quedar paralizada a mediados de agosto al sumarse sus trabajadoras —empujadas por «elementos extraños» al establecimiento, "entre los que se cuentan anarquistas conocidos"- a una huelga general declarada en la ciudad. El día 19 la dirección decretó su cierre, que se mantuvo algunos días. Tal fue la alarma que suscitaron estos hechos que el jefe de aquella dependencia recibió autorización y un "crédito secreto" de la dirección de Madrid para organizar, asesorado por el jefe de la comandancia de

${ }^{21}$ CAT (1920), pp. 7 y 10. Originariamente, la FTE se denominó «Federación Nacional de Cigarreras y Tabaqueros». Sus reivindicaciones - la mayoría de indole ptofesional (aumeneos salariales, contrataciones preferenres para las hijas de las cigarreras, ascensos por antigüedad, jornada de oho horas, reconocimiento del sindicato, etc.)-, en BaENA Luque (1993), p. 140 y Candela SOTO (1997), p. 175. También, ROMERo MASíA (1997), pp. 109-133.

Hispania, 1X/3, núm. 206 (2000) 1067-1126 
la Guardia Civil de Sevilla, un «servicio" que desenmascarase a los responsables de lo sucedido 22 .

En realidad, la agitación que se vivía formaba parte del proceso de reorganización de las cigarreras que se había abierto desde La Coruña. Este proceso culminó en el mes de octubre con la celebración en Madrid de una denominada «Asamblea General de Cigarreras y Tabaqueros», donde se constituyó la FTE citada con Severino Chacón como presidente y Luis N. Gómez como secretario. La Federación nació como un sindicato nacional afiliado a la UGT y dividido en 11 secciones distribuidas por las fábricas existentes en el país. Hasta julio de 1920, mes en el que se celebró el II Congreso tabaquero, el comité directivo del sindicato residió en La Coruña. En 1920 trasladó su sede a Madrid ${ }^{23}$.

La Compañía recibió cumplida información de la asamblea donde nació la nueva organización, asistiendo a estos hechos con mal disimulada preocupación, pero también con la esperanza de que el movimiento no levantara adhesiones generalizadas entre el personal de las fábricas: «asamblea para la cual, dijo [el director-gerente], se habían negado a designar representantes las operarias de la Fabrica de Madrid, y no podía asegurarse que los llegados de provincias, a quienes no se había concedido autorización para venir por sus respectivos Jefes, contasen con el asentimiento de todos sus compañeros.» En cualquier caso, los gestores del monopolio, conscientes de la trascendencia de lo que estaba ocurriendo, tenían perfectamente claro que no se iban a cruzar de brazos: "Añadió que se vigilaría el movimiento iniciado, para proceder según las circunstancias aconsejasen ${ }^{24}$.

La vida de la Federación Tabaquera no iba a resultar fácil en estos sus primeros años de existencia. A pesar del espíritu combativo que siempre había

22 En la fábrica de Sevilla, después de veinte años de ausencia de conflictos y desapego de la matcha general del movimiento obreto, se fundó en julio 1918 «Nicot», la federación local de cigarreras y tabaqueros. Efectivamente, un anarquista (Enrique Delgado) fue elegido presidente de una directiva integrada por trabajadores manuales, la mayoria hombres. En la misma no había obreras mecánicas ni maestras, es decir personal cualificado y de confianza de la dirección de la fábrica. A principios de 1919, Nicot se desligó de la CNT, descontentos sus miembros tras la estrategia seguida por los anarcosindicalistas, aunque en febrero de 1920 retornó a sus filas. Al final, esta vinculación le acarreó la ilegalización en enero 1921, cuando a instancias del gobernador civil de aquella provincia fue desbaratado el Sindicato Unico. Nicot arrancó en el verano de 1918 con unos 600 asociados; en 1920 sumaban ya 1.812 , esto es, el 92,5 por 100 de la plantilla de la fábrica. Esta información, en BAENA LUQUE (1993), pp. 121-160. Todas las comillas del párrafo, en ACAT, 22 y 29-VIII-1918. Sobre Chacón, CAPEL Martínez (1982), p. 254 y Candela Soto (1993-94), p. 110, e id. (1997), pp. 174-175. Pero, sobre todo, la excelente biografía que acaba de brindar RoMERO MASIA (2000), en su tesis doctoral sobre el sindicalista gallego.

23 Capel Martínez (1982), p. 254, Valdés Chápuli (1990), p. 88, Baena lueue (1993), pp. 141-142 y CANDELA SOTO (1993-94), p. 110. El encaje del sindicato sevillano dirigido por los anarquistas en la por entonces ugetista FIE, sólo se explica por el afán unitario de ésta y por su vocación de preservar a toda costa una gran autonomía en su toma de decisiones; vocación que presidió toda su historia hasta la Guerra Civil.

24 ACAT, 31-X-1918. 
caracterizado a las trabajadoras del tabaco en sus movilizaciones, muchas se resistieron ahora a ingresar en la organización. Lo cual, junto con los obstáculos interpuestos por la propia Compañía, que se negaba a reconocer a la nueva entidad, constituye una de las claves para entender la conflictividad en el sector durante estos años. La explicación de las resistencias a afiliarse por una buena parte del personal de las fábricas hay que buscarla en varios frentes. Por un lado, en la ausencia de una práctica asociativa continuada que superase el marco de las acciones momentáneas para superar metas concretas; por otro, en las reticencias y temores que despertaba la ideología - marxista - de la Federación; de otra parte, los altos salarios del sector, que favorecían el conformismo de las operarias; por último, no se ha de olvidar el miedo a perder el empleo, pues la Compañía se declaró dispuesta «a cortar de raíz el proceso asociativo aun contra las recomendaciones del propio gobierno que le pide respeto para la libre sindicación". La dirección de la Arrendataria puso en juego todos los medios a su alcance para acabar con la Federación: amenazas de despido a las obreras asociadas, coacciones directas, apoyo a las trabajadoras no sindicadas, creación, en último extremo, de asociaciones de otro matiz ideológico — católicas-, que actuaron a veces como organizaciones «amarillas" al servicio de la empresa... ${ }^{25}$ De hecho, los enfrentamientos entre las federadas y las «amarillas» fueron una constante en este período, realidad que pone en cuarentena el mito de la cultura solidaria de las cigarreras, que todavía recogen algunos historiadores con beatitud cuando hay pruebas más que evidentes que apuntan en sentido radicalmente contrario. Las cigarreras, como cualquier grupo social, podían tener sus diferencias internas, y de hecho las tuvieron, surgiendo con especial fuerza justamente cuando se trató de edificar una plataforma reivindicativa - la Federación Tabaquera- con la pretensión de monopolizar la representación de los trabajadores de esta industria.

Ese objetivo expansivo no se planteó siempre por métodos pacíficos. En realidad, lo que la Federación buscaba era el control del mercado de trabajo en la industria del tabaco, no dudando en amenazar con la expulsión del mismo a aquellas trabajadoras y trabajadores que se resistían a afiliarse o a acatar sus consignas. Es innecesario repasar todos los hechos que confirman lo dicho. Baste solamente un ejemplo. El 23 de noviembre de 1918, en pleno crecimiento de la FTE, estalló un motín en la fábrica de Sevilla que derivó en agresiones a las operarias llamadas «amarillas» y a algunas maestras, que fueron arrojadas de los talleres y se vieron obligadas a abandonar la fábrica. Los amotinados exigieron a la dirección de la fábrica y a las autoridades que fuesen despedidas definitivamente y que esa decisión se garantizase en un documento firmado. El jefe de la

25 Capel Martínez (1982), pp. 254-255 y Candela Soto (1997), p. 177. Según estas aucoras, en 1920 exiscían tres sindicatos cacólicos de cigarreras (fábricas de Gijón, Cádiz y San Sebastián), que, sin embargo, y de acuerdo con las propias fuentes católicas, apenas si reunían unas $\mathbf{4 8 0}$ afiliadas en Gijón y unas 80 en San Sebastián. Para Cádiz no disponemos de daros. 
fábrica se resistió a tal exigencia, pero se comprometió a que, en tanto se esclarecía lo ocurrido, estarían las acusadas sin ir a la fábrica. La dirección de la Compañía se pronunció a favor de preservar la libertad de trabajo en contra de las imposiciones sindicales, convencida de que detrás de estos acontecimientos había «un plan general trazado" "por ciertos elementos perturbadores». Tras celebrar consultas con el ministro de Hacienda, la fábrica de Sevilla se clausuró. Como respuesta a la expansión de la FTE, también fueron cerradas temporalmente las de Cádiz y La Coruña, donde se había producido una situación semejante ${ }^{26}$.

Pero la agitación continuó. Oficialmente, el año 1919 recogió cinco huelgas en el sector tabaquero, aunque de hecho fueron muchos más los conflictos producidos. En Alicante, la huelga general de marzo que paralizó la ciudad obligó a cerrar la fábrica, y en mayo, del día 24 al 26, se declaró un paro de brazos caídos en solidaridad con las cigarreras de Madrid, que no estaban de acuerdo con los últimos aumentos de premios concedidos por la empresa. En marzo, también, la fábrica de La Coruña inició una larga huelga en protesta por la política salarial de la Compañía, no aceptando una cláusula que establecía un descuento de dos pesetas diarias por cada falta de asistencia al trabajo no justificada. En Sevilla, a la altura del mes de abril, todavía se mantenía el enfrentamiento entre las asociadas a la FTE y las «amarillas", que por no haber querido sindicarse se vieron "por coacción" en la imposibilidad de trabajar (aunque la dirección de la fábrica, como había prometido, les mantuvo los jornales). Por esas fechas, la Compañía no se privaba de mostrar su alarma ante lo que estimaba una caída en picado de la producción y de los rendimientos, fruto tanto de los reiterados paros como de los aumentos de premios concedidos, que, sin embargo, no servían para frenar la espiral conflictiva.

A partir de mayo de 1919, la presión sindical se incrementó, y después del verano, en los meses del otoño y del invierno, la agitación alcanzó su cénit. La Compañía cerró algunas fábricas por periodos largos: las de Cádiz y Sevilla por bastante tiempo, de manera intermitente (la primera, sólo en los meses de verano estuvo cerrada 37 días); la de La Coruña desde el 11 de noviembre de 1919 hasta el 22 de marzo del año siguiente. Según la información oficial de la empresa, ello se debió a "causas completamente ajenas a la Compañía, derivadas de la lucha de bandos entre el personal obrero". Y en parte era cierto, aunque también tuvo mucho que ver la pretensión obrera de aumentar los premios, pues la implantación de la jornada de ocho horas en octubre había supuesto, de hecho, una reducción del salario a percibir. Los paros, en aquellos meses finales del año, se extendieron a casi todas las fábricas españolas. De hecho, fue declarada una huelga nacional de cigarreras y tabaqueras, que se alargó desde el 23 de diciembre de 1919 al 28 de enero de 1920. Aparte de las

26 ACAT, I4 y 21-XI-I918 y 28-XI-1919. El conflicto entre asociadas y «amarillas" había saltado ante la no aceptación de la estrategia de "Nicot" por parte de las segundas. Las asociadas consiguieron que se les apartara de la fábrica durante más de un año. Ver BaENA LUQUE (1993), pp. 151-154. 
fábricas mencionadas, también se vieron afectadas las demás: las de Logroño, San Sebastián, Valencia, Gijón, Bilbao, Santander, Madrid y Alicante. En esta última ciudad los paros comenzaron en noviembre y se prolongaron hasta el mes de enero siguiente. El balance del consejo de administración de la Arrendataria a final de año constituyó todo un poema de ribetes negros: pese a sus esfuerzos por contener "semejante campaña", el desorden y la indisciplina, alentados por "fines de política socialista" o "conveniencias de índole personal», se habían apoderado de las fábricas obligando al cierre de muchas de ellas. Tal gravedad alcanzaron los acontecimientos que una comisión de consejeros acordó visitar al ministro de Hacienda para recabar de él su asentimiento en la política que hubiera que adoptar. Una política que se explicitó abiertamente y cuyos puntos nodales eran el restablecimiento del principio de autoridad, el amago de lanzar un lock-out indefinido y la persecución de los responsables de este estado de $\cos ^{2}{ }^{27}$.

La ofensiva sindicalista todavía se mantuvo con cierto vigor en 1920, aunque ese año ofreció ya los primeros síntomas de agotamiento. La intensidad y el número de las huelgas fueron menores que en el año anterior. Las causas y la morfología de las mismas, empero, no se vieron alteradas, como tampoco la explicación que daban los gestores de la Arrendataria en su particular búsqueda de la raíz de estos conflictos: «disensiones entre los distintos bandos del personal», imposición coercitiva de «las agitaciones» «sugeridas por elementos extraños" a las fábricas, etc. Los más reseñables movimientos huelguísticos tuvieron lugar esta vez en Logroño y Madrid. Aquí los enfrentamientos entre «amarillas" y «chaconeras» adquirieron tintes dramáticos durante varias semanas. Como solución salomónica, la Compañía intentó separar en diferentes talleres a los dos bandos irreconciliables en los que se polarizó el personal. A la postre, la solución no satisfizo a nadie y el conflicto se prolongó. Pero el saldo final en este caso resultó negativo para las federadas y seguidoras del carismático Severino Chacón: 20 de las cigarreras «rojas» más significadas fueron purgadas y apartadas de la fábrica, siendo destinadas a trabajar en el almacén de la calle del General Lacy, lo que de hecho les supuso un castigo y una reducción considerable de sus ingresos, pues ese trabajo estaba peor remunerado ${ }^{28}$.

${ }^{27}$ En la huelga nacional se reivindicó un 50 por 100 de aumento salarial. El 19 de enero de 1920 la CAT propuso un incremento del 25 por 100. La Federación Tabaquera aceptó la oferta y ordenó la vuelta al trabajo. Ello no evitó, sin embargo, que en muchas fábricas se efectuaran expedientes disciplinarios contra las trabajadoras y trabajadores más significados en los conflictos. Cf. Capel Martínez (1982), p. 295; Valdés ChÁpuli (1990), pp. 98-100; Bafna LuQue (1993), pp. 142-145; ACAT, 14-V y 3-VII-1919, para la caída de la producción. ACAT, IV-1919, 25-IX1919 , I6 y 23-X-1919, 4 y 24-XII-1919, para las diversas huelgas. La cita entrecomillada del párrafo, en CAT (1920), p. 10. El balance de la CAT, en ACAT, 31-XII-1919. También, para La Coruña, ROMERO MASÍ́ (2000), pp. 211-237.

28 La valoración de la Arrendataria sobre la conflictividad de 1920, en CAT (1921), p. 9. El conflicto de Madrid está espléndidamente contado tanto en CAPEL MARTíneZ (1982), pp. 255-257, como en Candela Soto (1993-94), pp. 111-115 e id. (1997), pp. 178-184, que ofrece más detalles. 
Las divisiones entre las cigarreras y la actitud obstruccionista de la Compañía no lograron detener el proceso expansivo de la Federación Tabaquera, que poco a poco amplió su afiliación. En $1919 \mathrm{El} \mathrm{Sol}$ aseguraba que la cifra de federados era de unos 10.000 . Un año después, en 1920, fuentes socialistas hablaban de 3.220, pero sin contar los de seis fábricas, algunas tan importantes como las de La Coruña, Valencia, Cádiz y Bilbao, cuyos datos no se aportaban. Del 11 al 17 de julio de ese año la FTE celebró su II Congreso en Madrid. El objetivo más importante a esas alturas era englobar a todas las categorías laborales de la industria del tabaco, desde el más humilde mozo, pasando por las cigarreras y todo el organigrama jerárquico que éstas tenían sobre sus cabezas, hasta llegar al personal técnico-administrativo. Por entonces prácticamente todas las fábricas españolas contaban con representación en la Federación: La Coruña, Alicante, Valencia, San Sebastián, Logroño, Bilbao, Cádiz, Gijón, Sevilla y hasta Madrid, cuyo sindicato de cigarreras y tabaqueros había aprobado su reglamento el 29 de mayo (la única excepción era la de Santander y los motivos no están claros). En 1921, la Federación decía tener exactamente 9.675 afiliados. Ese año la FTE se separó de la central socialista y, durante algún tiempo, estuvo en la órbita de la III Internacional, lo cual tuvo que ser, sin duda, con el liderazgo de Chacón, perteneciente a la escisión que se separó del PSOE alumbrando en nacimiento del comunismo español. Tal giro ideológico hizo que los socialistas dirigieran duras críticas a este sindicato y a su líder histórico, Severino Chacón, que, pese a todo, continuó siendo el secretario general indiscutido de la FTE durante muchos años más ${ }^{29}$.

Después de 1920, la conflictividad fue mucho más puntual, hasta el punto de que las fábricas de tabacos se vieron más condicionadas por las huelgas ajenas al sector que por las suyas propias. Las huelgas del transporte, marítimo o terrestre, o las que afectaron a los contratistas de algún servicio de la Compañía (suministros de materias primas, envases, armado de cajones de embalar tabaco, etc.) resultaron más dañinas que los costes derivados de la propia anormali-

Este conflicto dio que hablar: un año más tarde reapareció en el Parlamento, coincidiendo con el debate en el Congreso del nuevo contrato de tenovación del monopolio a la CAT. L.os diputados socialistas Saborit y Besteiro intervinieron en defensa de «las cigarreras de Lacy» pidiendo el levantamiento del castigo al que habían sido someridas. De nada sirvíb. En 1923 fueron además cerrados los locales de Lacy y el personal empleado se quedó sin trabajo. Sólo en agosto de 1926 la Compañía decidió readmitir a las cigarreras.

29 De los cuarenta delegados presentes en el II Congreso veinticinco eran obreras. Sin embargo, pese a ser mayoría, sólo Angela Castro, representante de la fábrica de Cádiz, fue elegida para integrar la mesa de sesiones, compuesta por cuatro miembros en total. Para el comité se nombró presidente al madrileño Vivanco, y como secretario a Severino Chacón, de La Coruña. Cf. CAPEL MarTínez (1982), pp. 241-242, 254 y 257 y Barena LuQUe (1993), pp. 146-147. Para la cifra de 1921, véase la carta de la Federación Tabaquera Española al presidente del Congreso de los Diputados, Madrid, 18 de mayo de 1921, Archivo del Congreso de los Diputados, Sección General, leg. 460-14, legislatura 1921. Agradezco desde aquí a Miguel Martorell el haberme facilitado esta documentación. El giro comunista de Chacón, en ROMero Masí (2000), pp. 265-283. 
dad laboral suscitada en la empresa, cada vez más débil y escasa. El reflujo de la conflictividad tuvo que ver, sin duda, con el propio desgaste general de la agitación en España, así como con la contraofensiva patronal que se dio en el país desde 1920, que también tuvo su correlato en la industria del tabaco. Pero no menos influyó el hecho de que, a pesar de todo, la Compañía mantuvo una inteligente estrategia de concesiones y una política salarial que acabó dando sus frutos, detrás de la cual se escondía el deseo de salvar la producción en unos años en los que la mecanización se interrumpió, al cortarse las importaciones de maquinaria a causa de las circunstancias bélicas ${ }^{30}$.

Aparte de los sueldos - para el personal que lo tenía fijo, que era el menos (técnicos y administrativos)-, y el cobro del destajo regulado de acuerdo a unos premios de elaboración (para las cigarreras), la Arrendataria tenía organizado un complejo sistema de remuneraciones complementarias que actuaban a modo de pluses, extras y sobresueldos sin parangón en otros sectores productivos. Siempre que los trabajadores se veían impelidos a realizar una intensificación de labores, la empresa autorizaba religiosamente una gratificación. Desde el principio de la CAT existía también el denominado "fondo del 2 por 100 ", al que se recurría para la concesión de socorros individualizados a los empleados y obreros que la empresa estimaba oportuno. Por Navidad se solía conceder una paga en concepto de aguinaldo al personal administrativo y de las oficinas centrales de Madrid, equivalente a una mensualidad. Y luego estaban los donativos que anualmente se concedian al personal obrero para honrar la memoria de los prohombres de la Compañia, el más importante y duradero de los cuales fue el del marqués de Aldama instituido en $1908^{31}$.

Durante los años de 1918 a 1921 , la política salarial emprendida por la empresa asumió el firme propósito de neutralizar la inflación que se disparó durante la guerra mundial y coleó, tras su finalización, un año y pico más. Para ello se recurrió, por un lado, a la potenciación de las ayudas extraordinarias, y, por otro, a reiteradas subidas de sueldos y premios de elaboración. En cuanto a las primeras, es destacable la concesión de 300.000 pesetas hecha en 1918 por la junta general de accionistas en beneficio de los empleados de la Compañía: «en atención a las difíciles circunstancias creadas por la guerra». Periódicamen-

30 En la fábrica de Sevilla, por ejemplo, se dio algún tumulto entre diciembre de 1921 y marzo de 1922 en solidaridad con un empleado despedido. Pero el restablecimiento de la disciplina con la expulsión de los trabajadores que más se habian significado zanjó sin más el problema (ACAT, 29XII-1921, 23-II-1922, 2,9 y 16-III-1922). Ejemplos de huelgas ajenas que dañan los intereses de la Compañía, en ACAT, 27-XI-1919, 10-VI-1920, 1-VII-1920, 7-X-1920, 18-XI-1920, 9-XII1920, 23-VIII-1923 y 6-IX-1923. La contraofensiva patronal, en ReY REGUtiLo (1992). La salvación de la producción, en GÁLVEZ MuÑoz (1997), pp. 92-98.

31 Con ese fin se invirtieron 40.000 pesetas en fondos públicos, cuyos intereses se repartían anualmente entre unas cuantas operarias designadas por los jefes de las respectivas fábricas. También había otro fondo (de $23.679,60$ pesetas inicialmente) constituido con idéntico fin en memoria de Eleuterio Delgado y Martín, director-gerente de la Compañia de 1894 a 1909 , año en que falleció. Vex CAT (1909), p. 23, y los apéndices de las mernorias anuales de la Arrendataria. 
te fueron aprobadas otras dietas y gratificaciones con similar destino o en favor también del personal obrero ${ }^{32}$. En cuanto a las subidas salariales, se reiteraron en 1917, 1918, 1919 y 1920, y de ellas se beneficiaron tanto los trabajadores manuales como las maestras, capataces, porteros y el personal técnico y administrativo, que también fueron duramente golpeados por la inflación. Como en otros tiempos, cualquier cambio de labor que se ensayase suponiendo un recorte salarial llevó aparejada la correspondiente compensación, para que la capacidad adquisitiva de las operarias inmersas en tal reciclaje no se viese mermada. Además, en 1919 la Compañía gestionó del Estado - y se le concedió- la exención del impuesto de utilidades para los jornales del personal obrero. Con estos precedentes, que tuvieron su continuación durante la Dictadura de Primo de Rivera, no habrá de sorprender el balance ampliamente favorable que se puede hacer de la evolución salarial en la industria tabaquera entre 1914 y 1930. Un balance muy por encima del resto de oficios e industrias que empleaban mayoritariamente mano de obra femenina en el período ${ }^{33}$.

Consecuencia directa de la combatividad de las cigarteras y de las concesiones que se pudo permitir la Compañía Arrendataria - al fin y al cabo, un monopolio sumamente rentable- fue el notable incremento de la retribución base de las trabajadoras: ésta pasó, en términos de salarios-hora, de 0,28 pesetas en 1914 a 0,84 en 1930 , lo que supuso un incremento del 171 por 100 . La primera cifra era un 64,7 por ciento superior a la media nacional de los salarios de la mujer; la segunda duplicó tal media. La diferencia con el salario femenino inmediatamente posterior pasó de 5 a 35 céntimos. Con respecto a los salarios cualificados de los hombres, en términos de remuneración-hora media, el de la cigarrera era un 35 por ciento inferior en los años diez, mientras que al finalizar la década siguiente se redujo la diferencia a tan sólo un 8,7 por ciento. Además, fueton las únicas trabajadoras que consiguieron en 1920 un aumento del 25 por ciento en sus retribuciones como compensación de la reducción en sus ingresos a raíz del establecimiento de la jornada de ocho horas, aparte de conseguir una subvención diaria de dos pesetas más. La cuantía nominal del jornal diario de la cigarrera pasó, en fin, de 2,8 pesetas en 1914 a 6,7 pesetas en 1930. Por último, cabe indicar que, aparte de estas significativas conquistas salariales, la movilización de las cigarreras obtuvo otros frutos como la creación de sociedades mutualistas, cooperativas de consumo a cargo de los propios empleados o las creadas por la propia empresa, que concedió vales para determinados comercios y préstamos en condiciones ventajosas ${ }^{34}$.

32 Cf. ACAT, 7 y 11-IV-1918, 12 y 19-XII-1918, 16-I-1919, 15-IV-1919 y 20-I-1921.

33 Las cifras pormenorizadas, en REY ReGulLo (1998), pp. 59-60. Cf. CAT (1918), pp. 8-9; (1919), pp. 8-9 y 16-17; y (1920), pp. 10-11. Sólo la subida de 1917 supuso para la Compañía un gasto adicional de 1.291.880 pesetas (ACAT, 7-VII-1917). Para lo del cambio de labores, ver por ejemplo ACAT, 8-V-1918, referido a la fábrica de Gijón. Lo del impuesto de urilidades, en ACAT, 26-VI-1919.

34 Oficios de tradicional implantación femenina como las zejedoras e hiladoras tuvieron la siguiente evolución salarial, en términos de salarios-hora: las primeras pasaron de ganar 0,19 peseras 


\section{La negoclación colectiva en la Dictadura de Primo de Rivera (1923-} 1930)

Una vez producido el reflujo de la oleada sindicalista, en los años veinte la Federación Tabaquera Española emprendió una trayectoria independiente y muy personalizada en su líder Chacón, al margen de las dos grandes sindicales del momento (la anarcosindicalista Confederación Nacional del Trabajo, ilegalizada desde 1924, y la socialista Unión General de Trabajadores). A instancias de Chacón, la FTE eludió integrarse en ellas. Tampoco parece que la vinculación a la III Internacional se convirtiera en permanente: ni el escaso arraigo de los comunistas en España en aquella década, ni la obsesión antibolchevique de la Dictadura de Primo de Rivera propiciaron ese maridaje. Lo que sí se planteó, desde el marco de sus propias estructuras asociativas, fue el objetivo de constituirse en la célula originaria de una futura «Confederación de Monopolios» con vistas a integrar a los trabajadores de las industrias tabaquera, cerillera y de las recién creadas CAMPSA y Telefónica. En el ámbito estricto de la industria tabaquera, lejos de verse perjudicada por la nueva situación política, la Federación consiguió consolidarse como plataforma reivindicativa de los trabajadores en el sector, hasta el punto de dejar oír su voz directamente ante la Compañía. Contando con las aportaciones de sus militantes, logró comprar cien mil pesetas en acciones de la CAT, lo que le dio la posibilidad de asistir a las juntas de accionistas de la empresa e incluso discutir sus propuestas ${ }^{35}$.

El tener voz en la Compañía supuso todo un salto cualitativo, porque hasta ahora, de manera efectiva, esa voz siempre se le había negado a la FTE. Desde su nacimiento en 1918, la máxima reivindicación, como paso inicial para institucionalizar sus propuestas y demandas, había sido el reconocimiento como asociación por parte de la Compañía. Pero ese reconocimiento no había llegado. En 1921, aprovechando la discusión en el Congreso de los Diputados del nuevo contrato entre la empresa y el Estado, la Federación, por medio de los diputados socialistas pero también directamente, presionó con todas sus fuerzas para que la Arrendataria fuera literalmente obligada a respetarla como entidad representativa de los intereses de las cigarreras y tabaqueros. Así quedó expresado en varias cartas y telegramas enviadas al presidente del Congreso por las organizaciones subalternas de las fábricas, pero también por la propia Federación. Con ello se pretendía poner coto a los «innumerables atropellos», «los castigos impuestos" y «los despidos» injustificados» contra sus asociados, resul-

en 19I4 a 0,44 en 1930; y las segundas, de 0,16 a 0,42. La mayoría de los oficios osciló en torno a esas cifras, siendo pocos los que superaban las 0,20-0,25 pesetas en 1914 y las 0,47-0,52 en 1930. Para toda esta información y la recogida en el texto, CAPEL MARTíNEZ (1982), pp. 132, 135 y 155-158.

35 CAPEL MARTínez (1982), pp. 158 y 257. El acuerdo de ingresar en la junta de accionistas de la Compañía, como vía para hacer oír su voz ante la dirección, fue tomado por la FTE en su III Congreso, que se celebró en junio-julio de 1924. Cf. BAENA LUQUe (1993), p. 147, CANDELA SOTO (1997), pP. 184-189 y ROMERO MASÍA (2000), pp. 284-381.

Hispania, LX/3, núm. 206 (2000) 1067-1126 
tado de la «conducta persecutoria» de la Compañía Arrendataria contra la organización obrera ${ }^{36}$.

Con la Dictadura, la Federación Tabaquera tuvo desde fechas muy tempranas oportunidad de presentar sus propuestas ante las máximas instancias de la Compañía. La primera vez que hay constancia de que eso ocurrió fue en septiembre de 1924, en una junta extraordinaria de accionistas en Madrid. Allí, su líder, Severino Chacón, diseñó con todo lujo de detalles el que fue durante toda la historia del régimen de Primo el programa de actuación y el conjunto de reivindicaciones de la Federación, luego reiterado en otras ocasiones. Ese programa comprendía principios de carácter muy general, y otros más específicos relacionados con el régimen de trabajo en las fábricas. Respecto de los primeros, se pedía, en primer lugar, el reconocimiento por parte de la Compañía de la personalidad de la FTE así como de las asociaciones que la formaban, «tratando con sus legítimas representaciones de cuanto se relacione con los derechos y aspiraciones de los obretos de ambos sexos de las fábricas de tabacos». En segundo lugar, se demandaba una política de amnistía en relación con las movilizaciones anteriores a 1923, es decir la readmisión «de los obreros de ambos sexos» "que, por causas relacionadas con el ejercicio de los derechos de asociación, petición y huelgas fueron separados de la Compañía”.

En términos más concretos, se reivindicó acabar "con el régimen de favor» que supuestamente todavía regía en la contratación de nuevas aprendizas en algunas fábricas; que se redactase un nuevo reglamento interior de los establecimientos, «escuchando antes de su redacción los deseos de los obreros federados»; que dejasen de realizar «labores propias de hombres las obreras"; que se cumpliese la ley de la jornada legal de ocho horas; que se les abonase a las obreras parturientas el subsidio de maternidad, aprobado por el Estado en octubre de 1923; que a las obreras que trabajaban a destajo se les indemnizase la hora de trabajo diaria que invertían en dar el pecho a sus hijos; que se potenciase la higienización de los centros de trabajo; que se unificasen los premios de labores y sueldos del personal obrero de las diferentes fábricas, "poniendo fin a la irritante desigualdad que actualmente se mantiene en todas las labores y profesiones»; que se concediera al personal obrero el derecho de jubilación con el 75 por 100 del sueldo y se aumentara la cantidad que percibían las obreras destinadas a los talleres de "faenas auxiliares»; que se abonaran los sueldos íntegros en caso de enfermedad y accidente de trabajo; $y$, entre otras cuestiones menores, que se permitiera a los trabajadores el derecho a permutar y trasladarse de una fábrica a otra. La exposición de Chacón terminó con una serie de consideraciones relativas a la prohibición de toda clase de comercio, venta de bebidas alcohólicas y préstamos usurarios en los recintos fabriles; a la necesidad

36 Federación Tabaquera Española al presidente del Congreso de los Diputados, Madrid, 18 de mayo de 1921. Archivo del Congreso de los Diputados, Sección General, leg. 460-14, legislatura 1921. 
de incrementar las concesiones de la Compañía a las cooperativas de consumo del personal obrero, y de dar mayor impulso a las obras de transformación mecánica de los talleres, en pos de la contratación de nuevas obreras y obreros ${ }^{37}$.

Su presencia en la junta de accionistas - muy activa durante todos aquellos años- y la posibilidad de institucionalizar la práctica sindical en los órganos representativos de la Arrendataria no hizo que la FTE incrementara automáticamente su poder de influencia en la empresa. Inicialmente, el consejo de administración de la Compañía desestimó en bloque todas las propuestas referidas, unas por no tener razón de ser, puesto que de hecho ya se aplicaban: "por haber sido hechas ya sin excitación de nadie, otras por ser absolutamente imposibles, $y$ las demás por no ser convenientes». La más importante proposición, el reconocimiento de la Federación como plataforma representativa de los trabajadores, se rechazó frontalmente: «todos los estudios referentes al personal obrero los hace y los ha hecho la Compañía por propia iniciativa, tratando siempre directamente con los obreros mismos». Igual ocurrió con la propuesta de amnistía de los obreros despedidos por haberse implicado en actividades sindicales: «la Compañia (...) cuando ha separado a un obrero to ha hecho por la absoluta imposibilidad de continuar este formando excepción en el conjunto de los demás». También se rechazaron como exageradas, injustas o equivocadas las imputaciones relativas a la admisión de aprendizas, las obreras parturientas y lactantes, la jornada legal, unificación y aumento de sueldos y subvenciones, jubilaciones, traslados, prohibición del comercio en las fábricas, subsidios a cooperativas de consumo, instalaciones mecánicas, etc. La conclusión, en suma, era rotunda: «Por cuanto queda expuesto, el Consejo de Administración, tiene la honra de proponer a la Junta general que se sirva acordar no haber lugar a tomar en consideración las propuestas de que se trata» ${ }^{38}$.

Poco a poco, sin embargo, algunas de aquellas propuestas prosperaron. Eso sí, sin traspasar ciertos límites. La dirección de la Arrendataria terminó por plegarse a las peticiones de amnistía y desde mediados de 1925 se fueron produciendo las reincorporaciones, aunque con la advertencia explícita de que no se volvería a tolerar la propaganda sindical ni las luchas ideológicas en las fábricas, así como dejando claro que no se daría una solución uniforme a todos los afectados, sino que se analizaría cada caso de forma individualizada. En su conjunto, desde esas fechas se observó una actitud positiva en la Compañía, que se hizo eco implícitamente de muchas de las sugerencias vertidas desde tiempo atrás por la Federación Tabaquera. Si bien no lo reconoció nunca expresamente, bajo la convicción profunda de que llovía sobre mojado, en el sentido de que la empresa siempre se había adelantado a las propuestas obreras cuando estas eran razonables. Al fin y al cabo, como se argumentó en el consejo de administración, el Estado era el dueño de la Renta, mientras que la Compañía

37 Todas estas reivindicaciones, en ACAT, 27 y 28-IX-1924.

38 lbid. 
no era sino la administradora de la misma. A esas alturas, pues, las consecuencias de la mecanización y de las luchas sociales habían creado una situación que superaba el marco que perfilara en su día el reglamento de 1888 y obligaba a la confección de otro renovado. En 1925 la dirección de la empresa redactó el nuevo proyecto de reglamento del personal obrero: «en vista de los deseos de dicho personal y de la conveniencia de modernizar y reunir en un solo cuerpo las prescripciones por que se rija». Este reglamento configuró un régimen laboral para las fábricas de tabacos más moderno y notablemente sensible a las aspiraciones de los trabajadores. De hecho, también reflejaba las experiencias traumáticas habidas en el cruce de la segunda y tercera décadas del siglo al hilo de la marea sindical ${ }^{39}$.

Con cierto retraso, el documento fue aprobado por sendas reales órdenes del 13 de diciembre de 1926 y 14 de enero de 1927 . Desde sus primeros artículos, en el nuevo reglamento se advertía la gran trasformación experimentada por las fábricas. La importancia que en ellas habían alcanzado las máquinas se manifestaba claramente en las nuevas categorías creadas para el personal masculino: maquinistas, electricistas, ajustadores, torneros y forjadores, además de los oficiales que existían desde antiguo (carpinteros, albañiles, vidrieros, etc.). Con el personal femenino de los tradicionales talleres manuales se mantuvo la misma política de relegarlo en el uso de los nuevos artefactos. Para atender a las necesidades de los talleres mecanizados se abrió la puerta a nuevo personal, pero con la exigencia de una mayor y demostrada cualificación. Tanto es así que la instrucción de las obreras fue uno de los requisitos más cuidados por el nuevo reglamento. Abiertamente se persiguió la extinción de las operarias analfabetas y se dio alas a una mayor especialización en multitud de categorías. De modo que se establecieron las maestras de cigarros, las maestras de oreos y empaquetado, y las maestras de cigarrillos. En igual sentido que las maestras se especializaron las amas de rancho y las operarias. Al mismo tiempo se ordenó más al personal y se le exigió mayor limpieza (se acabó imponiendo, por ejemplo, el traje de trabajo reglamentario). Otro reflejo del cambio operado en el ámbito laboral se apreció en el horario, pues definitivamente se impuso la jornada de ocho horas tan reiteradamente exigida por la Federación Tabaquera. El sindicato continuó sin ser escuchado en lo relativo a sus peticiones de implantar un sistema de jubilación. Y lo mismo ocurrió con su reivindicación de sustituir el destajo por un salario mínimo y un sueldo anual, política de salarios que no era otra que la sugerida en la política social de la Dictadura. Algo se avanzó, pero no en el sentido apuntado por el sindicato tabaquero. El personal obrero empezó a cobrar de acuerdo a los sueldos, jornales, premios de elaboración y

39 Sesión extraordinaria del consejo de administración, ACAT, 3-VII-1925, ACAT, 6-VII1925 y Junta general ordinaria de accionistas, ACAT, 4-X-1925. El reglarnento de I888, en CAT: Reglamento orgánica... (1888). Para el régimen parricular de los empleados técnicos, CAT: Reghamento del ckerpo... (1897). 
créditos aprobados por el gobierno. Y estas remuneraciones se hallaron en función de la índole de los respectivos trabajos: conforme a cantidades fijas señaladas como sueldo o jornal; o conforme a cantidades fijas a las que se sumaron los premios de elaboración correspondientes en relación con la labor producida ${ }^{i 0}$.

$\mathrm{Si}$ en orden a las concesiones laborales, pese a todo, se percibió la influencia positiva de la Federación Tabaquera, en orden a la disciplina en el centro de trabajo esa influencia también se apreció, pero en sentido opuesto al establecido por aquélla. La experiencia de las movilizaciones sindicales pasadas latía en el artículado del nuevo reglamento de trabajo. En la medida de lo posible había que erradicar una hipotética vuelta atrás. De ahí que, junto a las faltas tradicionales (insubordinación a la autoridad, robos de tabaco, riñas, compras y ventas, fumar o encender fuego, abandonar el trabajo sin permiso...), se consideraran manifestaciones delictivas circunstancias no contempladas hasta ahora como faltas graves «a la disciplina y buen orden y régimen de las Fábricas»:

"Conducirse incorrectamente mediante conversación o frase que atente a la moral, ofenda a la familia, quebrante la disciplina o coaccione las ideas religiosas, políticas y sociales, que pueden profesarse libremente por todos, pero no ser objeto de discusión o propaganda dentro del Establecimiento.

Capitanear o dirigir agitaciones, trastornos o tumultos dentro de la Fábrica o señalarse o distinguirse en ellos, así como presidir, formar parte o auxiliar a comisiones que inicien o fomenten la agitación; considerándose agravada la falta en grado máximo si, como consecuencia de la anormalidad y sus efectos, resultase perjuicio de cualquier orden para los intereses de la Renta.

Inutilizar, destrozar o causar desperfectos en las labores, primeras materias, útiles y efectos de fabricación, máquinas, herramientas, instalaciones de energía, de luz, canalizaciones o distribuciones de agua; así como en el edificio y en los enseres y mobiliario mismo.

(...) La introducción en la Fábrica de armas de fuego, blancas o de cualquier clase, bastones, sean o no de estoque, y, en general, de cualquier elemento destinado al ataque o defensa personal.

La introducción de pólvoras, explosivos o todo elemento o materia de incendio o destrucción” 4 .

40 A las aspirantes ya no les bascó como antes, para ingresar, con un certificado del párroco. Ahora se les exigió tener catorce años cumplidos y menos de treinta; no padecer enfermedad crónica ni contagiosa y hallarse vacunada; saber leer y escribir, y acreditar buena conducta. Las disposiciones referidas a la enfermedad supusieron un progreso con relación a ocras épocas. En esa situación, se disponía que el personal obrero cobrara la mitad de su jornal durante un máximo de tres meses. Si los enfermos eran los descendientes o ascendientes de las operarias, se podía abonar a éstas, durante un plazo máximo de ocho días si habían de prestar asistencia al enfermo, la cantidad fija percibida como salario, no así el premio. Ver PÉRez Vidal (1959), pp. 292-295 y CAT: Reglamento referente... (1927), pp. 7 y 49-50. Un detallado balance de las transformaciones tecnológicas y productivas en el período de entreguerras, en COMín y MARTín ACEÑa (1999), pp. 257-305.

41 CAT: Reghamento referente... (1927), pp. 42-46. 
En el nuevo reglamento se atendió, en orden a prevenirlas, a «todas las manifestaciones, como se ve, de la lucha de clases». Considerada desde esa perspectiva podría afirmarse que la estrategia funcionó, pues en modo alguno se dieron durante la Dictadura elevados niveles conflictivos en las fábricas de la Renta. Lo cierto es que tampoco hizo mucha falta recurrir a los mecanismos preventivos. La conflictividad fue más bien puntual, inapreciable en muchos casos y, desde luego, no respondió a movilizaciones de envergadura alentadas por la Federación Tabaquera, que se abstuvo de lanzarlas. Lo más que se dio fueron presiones puntuales, siempre por vía institucional y dialogada, bajo los auspicios de algunas de las sociedades federadas en aras a mejorar las condiciones de trabajo de los empleados. Pero poco más. La evolución al alza de los salarios, de la que ya se ha hecho mención, la actitud positiva de la empresa tendente a realizar algunas concesiones, y la misma utilización de los cauces institucionales por parte de la FTE para exponer sus puntos de vista, ayudaron decisivamente a crear el clima de estabilidad laboral que presidió todo el período en este sector productivo. Lógicamente, en la imposición de la nueva disciplina fabril también influyó sobremanera que en los años veinte se reemprendiese - -ahora sin posible vuelta atrás- el proceso de mecanización y electrificación, que se vería consumado en la década siguiente ${ }^{42}$.

Por supuesto que las diferencias y desencuentros no escasearon. Es más, la dirección de la Compañía sabía perfectamente hasta donde podía llegar en su política dialogante. El límite se encontraba en todas aquellas propuestas sindicales que, desde el punto de vista de la empresa, pudieran poner su autoridad en cuestión, por mínimo que resultara ese cuestionamiento; la autoridad y, naturalmente, los costes de las concesiones a los trabajadores. Esas diferencias se pusieron de manifiesto cuando la Federación Tabaquera, por boca de Chacón, desempolvó la idea del control obrero en las fábricas, que tantos problemas y tantas tensiones había levantado en el mundo laboral español en general antes de 1923. La pretensión de que al personal obrero se le diera «intervención en la fabricación y una participación en las utilidades", esgrimida a cubierto de la crítica a los «imperfectos métodos de trabajo» que aplicaba la Compañía, levantó todo tipo de suspicacias y enorme revuelo en la dirección. En estas polémicas, a Chacón siempre se le contestó lo mismo: primero, que, a pesar de erigirse en representante de todos los trabajadores de las fábricas, él sólo encarnaba la voz de una parte de los mismos, y no precisamente la más numerosa; y, segundo, que su propuesta no engañaba a nadie, que el propósito de «la intervención" nunca se toleraría en cuanto que iba encaminado a minar la autoridad y el prestigio de la Compañía, siendo el resto de sus acusaciones sobre la política laboral aplicada "tópicos manoseados" y sin fundamento. El sueño del con-

42 Las comillas del principio del párrafo, en PÉrez Vidal (1959), p. 294. Las conclưsiones sobre la conflictividad se han deducido del seguimiento de las actas del consejo de administración de la Compañía Atrendatatia. Lo de la mecanización, en Gálvez MuÑoz (1997), pp. 99 y ss. 
trol obrero, que la Federación Tabaquera y Chacón - como otras organizaciones y líderes sindicales en su tiempo- esgrimieron de vez en cuando como la gran alternativa a la nefasta gestión capitalista, tuvo que esperat mejores tiempos para intentar ser llevado a la práctica ${ }^{43}$.

\section{La hegemonía de la Federación Tabaquera en la II República (1931- 1936)}

El período republicano abrió las puertas a la consolidación del sindicalismo tabaquero en España, después de largos años de laborioso avance asociativo y de falta de reconocimiento por parte de la Compañía. En estos años la Federación aseguró que afiliaba a la casi totalidad de los asalariados de la industria tabaquera. Conforme a sus cifras, reunía cerca de quince mil afiliados, en el bien entendido que no sólo integraba al personal obrero de las fábricas, sino también a buena parte del personal técnico y administrativo, a los expendedores de los estancos y a los cultivadores del tabaco. De ser cierta tal estimación, revelaría su gran potencial porque, según datos del Ministerio de Trabajo, en las fábricas de la Arrendataria estaban empleados a esas alturas 14.256 trabajadores, de los que 12.570 -el 88,17 por 100 - eran mujeres ${ }^{44}$.

Hasta 1933, la FTE mantuvo sus tradicionales 11 secciones locales en aquellas ciudades donde se hallaban asentadas Ias fábricas (Madrid, Alicante, Valencia, Sevilla, Cádiz, La Coruña, Gijón, Santander, Bilbao, San Sebastián y Logroño). Tras la inauguración de la de Tarragona en 1933 también amplió su radio de acción a este establecimiento. En algunas de las ciudades mencionadas tenía organizados centros sociales y cooperativas, ámbitos donde transcurría la vida asociativa de las diferentes organizaciones que componían la Federación. Formalmente ésta mantuvo la más estricta independencia bajo el deseo de que todos los trabajadores se sintieran cómodos, fueran cuales fueran sus creencias y convicciones ideológicas. No obstante, las simpatías filocomunistas de algunos de sus líderes llevaron a la Federación Tabaquera a respaldar el movimiento sindical de ese signo, con el que compartió su filosofía frentista proclive a conseguir la unidad sindical de los trabajadores. De este modo en julio de 1932 se adhirió a la Conferencia de Unidad Sindical, celebrada bajo los auspicios de los comunistas. Cuando éstos crearon en 1934 la Confederación General del Trabajo Unitaria, la Federación Tabaquera volvió a adherirse a la iniciativa. Pero en noviembre de 1935 la CGTU se integró en la UGT siguiendo la estrategia unitaria propiciada por la III Internacional como forma de frenar «el peligro fascista». Entonces, la Federación Tabaquera se quedó al margen, convencida

${ }^{43}$ Junta general ordinaria de accionistas, ACAT, 15-IV-1928. Un análisis del sueño del control obtero, en REY REGUILLO (1989-1990).

44 Las cifras, en NúN̄eZ PéreZ (1989), p. 175.

Hispantia, LX/3, núm. 206 (2000) 1067-1126 
de que la integración de los trabajadores del ramo debía realizarse aprovechando sus estructuras y no las de otras organizaciones ${ }^{45}$.

Fuera de la Federación Tabaquera, en otras organizaciones sindicales militaban muy pocos trabajadores del sector. A principios del período, los socialistas propiciaron en Madrid una escisión y crearon su propio sindicato tabaquero: "Vindicación", que en modo alguno llegó a producir una sangría en la federación de Chacón. Según el Censo Electoral Social de 1934, sólo había 480 afiliados a la UGT como representantes de la industria del tabaco (de los que 294 era mujeres). En la fábrica de La Coruña, por su parte, los anarquistas y sindicalistas de la CNT sostenían una pequeña organización, ahora revitalizada, que habían impulsado en los primeros años veinte. Parece que en la fábrica de Santander también se formó un pequeño sindicato de estas características. En lo que se refiere al sindicalismo católico, que había disfrutado de cierta fuerza con anterioridad a la Dictadura de Primo de Rivera (con gran aceptación entre las porteras, maestras, amas de rancho y un segmento importante de las cigarreras en algunas fábricas), da la impresión de que en la República sobrevivió a duras penas. De acuerdo al citado censo de 1934, en la sección de cigarreras de la Federación de Sindicatos Obreros Femeninos de Nazaret (constituida el 12 de enero de 1919) sólo había inscritas 288 trabajadoras ${ }^{46}$.

Dado su indiscutible predominio, las directrices sindicales en la industria del tabaco durante los años republicanos vinieron marcadas por la Federación de Severino Chacón, que todavía aparecía como el líder carismático de la entidad. En esa práctica sindical se apreció una clarísima línea de continuidad con el período de la Dictadura, si acaso, hasta 1934, con una mayor profundización en sus posiciones. La Federación trató de explotar a su favor el hecho de que saliera un gobierno de izquierdas - republicano y socialista- de las elecciones legislativas de junio de 1931. Esta circunstancia modificó de raíz el marco de relaciones de la Arrendataria con sus trabajadores, pues, al fin y al cabo, era una empresa que gestionaba un monopolio público. Un monopolio público donde las autoridades del Estado, por medio del representante del gobierno, no sólo se permitían opinar, sino que tenían que autorizar la mayoría de las decisiones que se tomaban, incluidas las referidas al ámbito laboral. Es más, la cartera de Trabajo y la de Hacienda - las dos con las que más dependencia mantenía la Arrendataria - recayeron en manos de dos socialistas, Indalecio Prieto y Francisco Largo Caballero. Y aunque las relaciones de la Federación Tabaquera con la UGT, el sindicato socialista, no fueron precisamente idílicas, ninguno de aquellos dos ministros legisló o actuó en contra de los trabajadores de

45 NứNEZ PÉreZ (1989), pp. 642-643 y ROMERo MASíA (2000), pp. 382-459.

46 Para los católicos y la afiliación a la UGT, NúNËZ PÉreZ (1989), pp. 589 y 615. El dato de Santander, en LERMa BRAGado y otros (1991). Lo de La Coruña y la noticia sobre Vindicación, se ha extraído de la consulta de ACAT y de Unión Tabacalera, el órgano de prensa oficial de la FTE hasta diciembre de 1935, en que cambió su denominación y pasó a llamarse Federación Tabaquera Equañola. También, ROMERO MASIA, op. cit. 
esta industria. Los bajos índices de conflictividad registrados en las fábricas de tabacos por motivos estrictamente endógenos hasta 1933 (año en que se agota la etapa republicano-socialista) constituyen un buen indicador en ese sentido.

La práctica sindical de la FTE durante toda la República podría definirse como gradualista y pragmática. Sus reivindicaciones se ciñeron a fines estrictamente laborales: la defensa de la jornada de ocho horas, los aumentos salariales, el establecimiento de un sueldo base y la tendencia a la unificación salarial, la abolición del destajo, el impulso a nuevas contrataciones, la demanda de un sistema de jubilaciones, el perfeccionamiento y ampliación de los seguros sociales y de la previsión laboral, la mejora de las condiciones higiénico-sanitarias en las fábricas... Una novedad en esta época fue que la Federación ya no se limitó a hablar en nombre de los trabajadores manuales. Ahora amplió su esfera de influencia a los empleados administrativos, al personal del resguardo terrestre y marítimo, a los marineros, a los técnicos, a los inspectores, a los médicos, a los expendedores y hasta a los cultivadores, en un afán evidente por convertirse en portavoz de todos los intereses y categorías laborales dependientes de la Renta. Su posibilismo de fondo, empero, no privó a la Federación de mantener un discurso izquierdista con resabios anticapitalistas. Más en concreto, un discurso contrario a la gestión privada del monopolio estatal, con el argumento genérico de que los resultados conseguidos por la Arrendataria se podrian mejorar ampliamente por medio de técnicos dependientes directamente del poder público, que, además, contarían con el asesoramiento entusiasta del sindicato y de sus trabajadores, supuestamente mucho más duchos y experimentados que la Compañía en todo lo relativo a cuestiones técnicas y productivas. Otro argumento que se esgrimió fue el consabido de que resultaba intolerable que una empresa pública que generaba tantos beneficios fuera explotada por manos privadas, cuando lo suyo era que esa rentabilidad tuviera una proyección exclusivamente social. Obviamente, la filosofía del "control obrero», de la intervención de la empresa por los trabajadores, guiaba de manera explícita todo ese discurso ${ }^{47}$.

El realismo pragmático de la FTE dio sus frutos antes incluso de llegar a contar con un contexto político favorable a partit de 1931. En plena «Dictablanda» fueron aprobadas unas bases salariales de carácter general que mejoraron ostensiblemente los niveles previos, ya de por sí superiores a la mayoría de los restantes sectores productivos como se ha señalado más arriba. También, por primera vez, se abrió la puerta a las vacaciones anuales: desde este momento, los jefes de fábrica quedaron facultados para conceder al personal hasta

47. Las reivindicaciones se plantearon siempre que hubo una junta general de accionistas en la Compañía por boca de Severino Chacón o Eulalia Prieto, líder histórica también de las cigarreras, que asumió responsabilidades representativas en estos años, por las que luego, a raíz de los sucesos de octubte del 34, fue castigada con la expulsión de su puesto de trabajo durante ocho meses (ver más adelante). Cf., por ejemplo, ACAT, 13-IV-1930, 12-IV-1931 y 10-IV-1932. El discurso anticapitalista se mantuvo más bien de puertas a dentro, cara a los militantes y afiliados, como se desprende del seguimiento de su órgano oficial, Unión Tabacalera. 
quince días de licencia pagados al año. Como en otras ocasiones, la política de subidas salariales benefició a su vez a las operarias pertenecientes a los «talleres especiales de carácter auxiliar», es decir, a las trabajadoras ancianas incorporadas a ese particular sistema. En mayo de 1934, otra orden ministerial elevó de nuevo con carácter general los sueldos y premios de elaboración de los empleados. Posiblemente, estas subidas, que no hacian sino ajustarse a las reivindicaciones previas de la FTE, constituyeron una razón de peso para explicar el escaso número de paros laborales registrados en la industria del tabaco por razones específicas del sector, $y$, más en particular, para entender por qué casi ninguno de esos paros se produjo por motivos salariales ${ }^{48}$.

Esto no significa que las fábricas de tabaco se quedaran por completo al margen de la intensa secuencia conflictiva de la II República. Esa secuencia influyó en los trabajadores del tabaco. Pero aquí es obligado distinguir, por un lado, la conflictividad propia - a todas luces escasa para lo que fue el contexto dominante-, y la agitación general, que por vía indirecta paralizó la producción repetidas veces en la Compañía Arrendataria. Por consiguiente, esta segunda variable conflictiva, de naturaleza no siempre laboral, más que nada les vino impuesta a los asalariados de la industria del tabaco, con independencia de que alguna minoría suscribiera con entusiasmo los paros que se derivaron de la misma. Es conocido que las estadísticas oficiales del momento no son totalmente fiables, pues muestran grandes vacíos y no recogen la totalidad de los conflictos. Pero no deja de ser representativo que el Boletín del Ministerio de Trabajo ofrezca un recuento de tan solo 12 huelgas en todas las fábricas de tabacos entre 1930 y 1936: como lo es también que se concentren en 1931 (una huelga) y sobre todo en 1933 (cuatro) y 1934 (siete), figurando completamente en blanco los años de 1930,1932, 1935 y 1936. Obviamente, estas cifras se refieren a las huelgas específicas del sector tabaquero. Por número de huelguistas y de jornadas perdidas, el año más duro fue el de 1933, con 5.261 parados y 41.554 días respectivamente. Esto se explica porque fue justamente entonces cuando quebró la coalición republicano-socialista gobernante, lo cual tuvo una repercusión negativa en la política laboral, que se tradujo en el incremento de los conflictos. En 1934, aunque se registró un mayor número de huelgas, el

48 De las doce huelgas oficialmente registradas en la industria del tabaco desde enero de 1931 a junio de 1936 solamente una se produjo por motivos salariales (NúṄEZ PÉrEZ (1989), p. 364). Que las subidas salariales respondía a las peticiones de la FTE se confirma en las actas del Consejo de administración (ACAT), donde se da cumplida cuenta de esas demandas. En relación a la política salatial de la Compañía, cabe indicar que ya una R.O. del 19 de julio de 1929 concedió importantes mejoras al personal obreto de las fábricas y depósitos de la Renta. Otra R. O. de 31 de dicsembre dispuso ampliar y mejorar los servicios médico-fatrnacéuticos en las fábricas. Ver CAT (1930), PP. 17-19 para las cifras y más pormenores. En 1930 las mejoras siguieron lo dispuesto en sendas reales órdenes del 19 de noviembre y del 6 de diciembre. Ver CAT (1931), pp. 16-18. Otcos aumentos se consiguieron por orden ministerial de 8 de julio de 1932 y 24 de mayo de 1934. Ver CAT (1933), p. 19 y (1934), p. 15. También, REY REGUILIO (1998), pp. 70-71. 
número de trabajadores implicados no fue muy superior al del año anterior (5.725), como tampoco el número de jornadas perdidas, que incluso disminuyó ostensiblemente (13.886). En ambos años, con todo, la proporción de obreros en huelga sobre los ocupados en aquellas fábricas afectadas por los paros ascendió al cien por cien. Las causas tuvieron que ver con motivos referentes a la asociación, a la política de personal aplicada y a la organización del trabajo ${ }^{49}$.

Más paros se sucedieron e incluso más crispación se generó como consecuencia del reflejo que la conflictividad general del período tuvo en las fábricas de tabacos. En este sentido, la Compañía Arrendataria desempeñó el papel de caja de resonancia de la protesta social en la coyuntura republicana. Fueron numerosísimas las huelgas que se produjeron en solidaridad o como fruto de los efectos de arrastre de las huelgas generales que se multiplicaron entonces, muchas veces convocadas por los anarcosindicalistas, pero también por los comunistas o los socialistas a partir de un cierto momento, y por motivos más políticos que laborales en sentido estricto. Por supuesto que muchos asalariados del tabaco estaban tan politizados como los del resto del arco productivo -en una época como aquélla en la que resultaba difícil evitar la ideologización de los conflictos del trabajo-, pero también es verdad que en un gran porcentaje de esos conflictos el personal tabaquero se sumó porque no le quedó más remedio. La acción contundente de los piquetes atemorizaba a los trabajadores, que temían ser objeto de agresiones, hasta el punto de rendirse a la primera de cambio ante las amenazas disuasorias de aquéllos. Buena prueba es que la Compañía, en la mayoría de estas ocasiones, excusó el paro de sus asalariados y no tuvo reparo alguno en darles cobertura salarial por los días en los que no se trabajó, pese a los altos costes generados, que le producían verdadera alarma. Eso sí, cuando la Compañía tuvo constancia de que la adhesión a la huelga general o la solidaridad con algún otro conflicto fue voluntaria, entonces automáticamente se aplicaron los descuentos correspondientes ${ }^{50}$.

49 NúŃẼEZ PÉrEZ (1989), p. 436. Ejemplos de conflictos de esta naturaleza son, por citar algunos, los siguientes: la huega del 29 de noviembre en la fábrica de Alicante rechazando el plan de remuneraciones que acababa de aprobar la Compañía, que no satisfacía sus aspiraciones (VALDES CHÁPUL (1990), p. 101); la negativa del personal de desvenado en la misma fábrica a trabajar un tabaco de mala calidad (y de bajos rendimientos por tanto) que tuvo lugar en mayo de 1932 (ACAT, 2-V-1932); el plante general que se dio también alli en el mes de marzo anterior para impedir la salida de máquinas propias hacia la recién inaugurada fábrica de Tarragona y exigiendo, por contra, el ingreso de nuevas aprendizas de la ciudad (ACAT, 14-11I-1932); o la protesta por idénticas razones de los obreros de la fábrica de Logroño dos meses después (ACATT, 2-V-1932).

50 Así ocurrió con los trabajadores de la fábrica de San Sebastián que faltacon al trabajo el $1^{\circ}$ de mayo de 1930 (ACAT, 12-V-1930); la huelga general de mediados de diciembre de ese mismo año, ante la que hubo muchos trabajadores que se sumaron por iniciativa propia (ACAT, 18-XII1930); el paro de solidaridad por los sucesos de Arnedo que suscribieron los trabajadores de la fábrica de Logroño (ACAT, 11-I.1932); o las sendas huelgas generales declaradas en La Coruña, Bilbao y Sevilla en enero de 1932 (ACAT, 1-II-1932). Pero también abundaron los casos de paros impuestos en los que los tabaqueros y cigarreras cobraron religiosamente sus jornales, por ejemplo: la huel- 
La dirección de la Arrendataria no se mantuvo impasible ante la creciente inestabilidad social y política. Tampoco vio con indiferencia el fortalecimiento de la Federación Tabaquera, que se tradujo por momentos en un incremento sin precedentes de las concesiones y de las cargas laborales. Por no hablar de la intranquilidad que despertó en la empresa la retórica crítica y las estridencias verbales que se vertieron contra ella desde Unión Tabacalera, de las que se tomaron cuenta puntualmente y sirvieron después como argumento de recriminación de la ejecutiva a los representantes de la FTE en la junta de accionistas. Pese a todo, la Compañía siguió cuestionando el derecho del sindicato a representar los intereses de los trabajadores en las fábricas, en lógica respuesta al discurso de la Federación cuestionando la razón de ser de la Arrendataria como gestora del monopolio. Que la conflictividad, las huelgas y la violencia que a menudo se desprendieron de ellas preocuparon en la empresa fue una verdad a voces. Era natural desde su óptica, por tanto, que la Arrendataria - como toda la clase empresarial en su conjunto- hiciera llamadas desesperadas a las autoridades para que se preservara el orden público. En esa línea, como ya hiciera en los años finales de la Restauración o en el siglo XIX, la Compañía no escatimó medios ni dinero a la hora de respaldar a las fuerzas de seguridad del Estado. Incluso llegó a reforzar sus propios mecanismos defensivos, no dudando en mejotar y ampliar el armamento de sus cuerpos privados de seguridad.

A raíz de la sublevación de Jaca y el frustrado movimiento revolucionario que se intentó, una junta presidida por el duque de Fernán Núñez y los periódicos $A B C$ y $E l$ Debate abrieron sendas suscripciones para rendir homenaje a los institutos armados y reunir fondos para la Guardia Civil y a las familias de las víctimas. La Compañía aportó la nada despreciable cifra de 20.000 pesetas a la primera suscripción, y otras 5.000 a cada una de las abiertas por los citados periódicos. En marzo de 1932, la Arrendataria aprobó un presupuesto para la compra de pistolas automáticas «Star» y cargadores para los vigilantes de la fábrica de Madrid. El 30 de junio de ese mismo año, conforme a lo solicitado por la Arrendaria, se publicó una orden del Ministerio de la Gobernación concediendo licencias gratuitas de uso de atmas a los cajeros, guardalmacenes, administradores subalternos, ordenanzas y serenos de la Compañía, «tanto a los que prestan servicio en la Dirección de la misma como en las fábricas y representaciones, y a los dependientes de la expendeduría central de Madrid». En julio, la CAT hizo gestiones ante el ministro de la Gobernación para que tam-

ga general de Sevilla el 23 de junio de 1930 (ACAT, 30-VI-1930); la huelga general de San Sebastián el 8 y el 9 de de enero de 1932 (ACAT, 11-1-1930); las huelgas generales declaradas en Cádiz y Sevilla en febrero de ese mismo año (ACAT, 15-1I-1932); la huelga general de Cádiz y la huelga general de la construcción de San Sebastián declaradas en el mes de mayo siguiente (ACAT, 9 y 30 V-1932); y la huelga que paralizó La Coruña en el mes de junio (ACAT, 13 y 20-VI-1932). Tanzo VALDÉS CHÁPULI (1990), pp. 100-102, para Alicante, como LeRMA BRAGADO y otros (1991), para Santander, brindan más ejemplos de paros solidarios o impuestos por las circunstancias en las fábricas de tabacos. 
bién se les concediera gratuitamente licencia de uso de armas a los expendedores de tabacos de la provincia de Cáceres que así lo habían solicitado: «ante los repetidos atracos de que son objeto las expendedurías y por el estado social de la provinciams1.

Los sucesos de octubre de 1934 cambiaron durante un tiempo la correlación de fuerzas que la República había conformado en el mundo del tabaco, claramente favorable a la FTE. Aquellos acontecimientos dieron la excusa a la Compañía para intentar la rectificación del rumbo que se había impuesto en las relaciones laborales del sector desde 1931. En las fábricas de tabacos no dejó de repercutir la agitación de octubre, cuyo epicentro lo compartieron Asturias y, en menor medida, Cataluña. Como consecuencia de las huelgas declaradas en solidaridad con el movimiento insurreccional, «hubieron de cerrarse, de acuerdo con el Gobierno y en consonancia con las determinaciones por él adoptadas, algunas de las Fábricas de Tabacos». La Compañía amenazó con rescindir sus contratos a las obreras y obreros que no acudieran de inmediato al trabajo. Pero en varios establecimientos, a pesar del anuncio del despido automático, el personal no se presentó. La dirección de la Compañía actuó en consecuencia: "por no haber atendido los requerimientos que se hicieron oportunamente para evitar perjuicios al personal obrero, se despidió al de las Fábricas de Alicante, Madrid, Santander y San Sebastián». En algunas fábricas, los vigilantes, el personal de oficinas, las maestras y los trabajadores afines hicieron causa común con los jefes para prevenir posibles desmanes o ataques de los huelguistas. Especialmente «meritoria y digna de elogio» fue para la Arrendataria la conducta del representante de la Compañía en Ásturias, del jefe de la fábrica de Gijón y de los empleados y «otro personal» que se mantuvieron a sus órdenes «durante los nefastos acontecimientos ocurridos en aquella provincia». Los daños ocasionados a la Renta por la revuelta de Asturias según informes de la propia empresa parece que fueron de consideración, "pero no de tanta como hicieron presumir las primeras noticias» 52 .

A finales del mes de octubre y durante el mes de noviembre de 1934 se readmitió al personal en su casi totalidad. Pero se efectuaron purgas y se descontaron los jornales de los días de huelga. En el primer momento fueron suspendidos de empleo noventa y cuatro obreros de ambos sexos en las citadas fábricas de Alicante, Madrid, San Sebastián y Santander. A los dos meses de la suspensión se dio orden de reingreso a sesenta, dejando en la calle, en calidad de despedidos definitivos, a los treinta y cuatro restantes ( 27 de Alicante y 7 de

s1 Todas esas noticias, por orden de cita, en ACAT, 22-XII-1930; 5-III-1932; 11-VII-1932 y 4-VII-1932. La actitud de las clases empresariales ante la conflictividad y el desorden social en escos años, en CABRERA (1983). La zendencia a armarse de los seccores socìales conservadores, en GONZÁLez Calleja y Rey Reguillo (1995).

52 CAT (1935), pp. 13-14 y 23. Después de los sucesos, a varios expendedores de Asturias se les concedió una saca gratuita de tabacos y timbre por el importe que fijaron los funcionarios del Estado y la Compañía, contando con la aprobación del Ministerio de Hacienda. 
Madrid). Al personal readmitido se le exigió el firme compromiso de respetar las condiciones impuestas por la empresa, que fijó un año de prueba en el que los trabajadores debían demostrar buena conducta, no estando exentos de ser despedidos a la primera de cambio. Motivo para ello podría ser cualquier acto de rebeldía o de desacato a los jefes en las fábricas, así como toda manifestación política dentro de las mismas ${ }^{53}$. La empresa hizo una declaración de principios paternalista apelando a la armonía, detrás de la cual se encontraba, en realidad, el firme propósito de preservar a toda costa el principio de autoridad, así como el deseo no confesado de mermar al menos, cuando no liquidar, el potencial reivindicativo y desestabilizador de la Federación Tabaquera. Por medio del director-gerente, Luis de Albacete, el consejo de administración dio las órdenes oportunas a los diferentes jefes de fábrica -amenazándoles con exigirles responsabilidades si no se cumplían los dictados establecidos- para que una situación como la vivida no volviera a repetirse. El punto de partida para mantener la disciplina en las fábricas debía ser la rígida normativa estipulada en el Reglamento de 1927 que, como se ha indicado más arriba, fijaba en términos duros y muy pormenorizados el régimen de conducta y trabajo del personal obrero, su despolitización y su asepsia sindical dentro del recinto fabril:

«Por eso, al menor conato de indisciplina o de confabulación para producirla que observe V. adoptará V. las medidas del caso para sofocar o prevenir la rebeldía, procediendo, si fuera preciso de acuerdo con la autoridad superior de la provincia, a fin de evitar que el personal obrero de las órdenes de V. cuyos derechos de ciudadanía y libertad de pensamiento se ha de respetar en absoluto, se asocie en una u otra forma como tal a movimientos y manifestaciones políticas. Ese personal no debe hacer dentro de la Fábrica otra cosa que atender a su trabajo, sin que en ella quepa tolerar partidismos, ni banderías de ninguna clase, ni nada que cohiba el uso de las atribuciones y facultades que reglamentariamente cortesponden al jefe y sobre cuya conservación íntegra y eficaz debe $V$. velar cuidadosamente y celosamente, pues cualquier claudicación o debilidad en punto de tanta importancia para el buen régimen de los servicios es de suma trascendencia y de consecuencias funestas, pudiendo acarrear responsabilidades que sería doloroso tener que exigir ${ }^{54}$.

La mejor demostración de los deseos de la Compañía se constata reparando en el hecho de que entre los despedidos con carácter definitivo se encontraba la plana mayor del comité ejecutivo de la Federación Tabaquera: Eulalia Prieto, presidenta; María Bona, vicepresidenta; León Izquierdo, vicesecretario; María del Apio, contadora; y los vocales del sector obrero Agapito Gismero y Jeróni-

33 CAT (1935), pp. 13-14. Los datos sobre los despedidos, en «Solidaridad", Unión Tabacalera, X-1935, p. 10. Las condiciones de la readmisión, en LERMA BRAGADO y otcos (1991).

34 Carta de Luis de Albacete al administrador jefe de la fábrica de Santander, Madeid, 13-IX1934, cit. en LERMA BRAGADO y otros (1991), apéndices. 
mo de Dios. Todos ellos eran personas que gozaban de la total confianza del secretario general, Severino Chacón. Naturalmente, la Federación recibió el año de 1935 «bajo los auspicios más dramáticos" y "los más tristes presagios», advirtiendo sobre Io insensato que sería abrir un "ciclo de involución" en la pretensión de rectificar las conquistas obreras del primer bienio republicano. Con el tono del discurso rebajado, aunque sin renunciar a las líneas de actuación laboral que venían presidiendo su estrategia, la Federación dio preferencia durante el año al sostenimiento de los improvisados mecanismos de ayuda a los represaliados. Para ello abrió un fondo de solidaridad, que repartió en concepto de abono de jornales una cifra próxima a las cien mil pesetas, gracias a lo cual nunca les faltó de nada a aquéllos. Al mismo tiempo se pidió en todas las instancias su readmisión, que al final, gracias a la mediación del representante del Estado en la Compañía ante el nuevo ministro de Hacienda (Joaquín Chapaprieta), fue posible tras ocho meses de haberse producido las expulsiones. El gozo, más bien auténtico júbilo, de los trabajadores federados fue indescriptible. También se fueron abriendo los centros sociales tabaqueros que habían sido clausurados. Donde más resistencia hubo por parte de la empresa fue en la fábrica de Alicante, por «la cerril intransigencia» de su jefe que, según los afectados, "quiso quebrar la Federación" en la localidad"s.

A partir de entonces proliferaron más que nunca las llamadas a la unidad de los trabajadores del tabaco. La Federación de Chacón reiteró sus ofertas a los disidentes anarcosindicalistas de La Coruña, con el argumento de que las divisiones habían redundado en la no consecución de mejoras importantes en aquella fábrica, tras diez y ocho años de desencuentros. Las mismas ofertas se hicieron al sindicato socialista "Vindicación», de Madrid: «marcaríamos un nuevo rumbo que a todos produciría considerables beneficios». En octubre de 1935 se aseguraba desde Unión Tabacalera que las negociaciones iniciadas para acabar con la división iban por buen camino. Claro que la concepción unitaria de la FTE no era la de los socialistas o la de los cenetistas. No se consideraba a sí misma una federación de industria más, sino «algo que puede denominarse una central de industria, ya que sus fuerzas están diseminadas por todas las provincias de Españan. Por eso, por declararse amiga de todas las centrales existentes (UGT, CNT, CGTU), por apoyar todas las iniciativas de efrente único» y por considerarse elemento aglutinante de todos los trabajadores del tabaco frente a

"Cf. «Solidaridad", Unión Tabacalera, X-1935, p. 10. Las líneas de actuación laboral, por ejemplo, en $\alpha$ Es preciso un inteligente reajustes, ld., II-1935, p. 1, donde se habla otra vez de tender a la nivelación de jornales en las distintas categorías laborales, de reajustar los grupos de elaboración en las fábricas, y de dar intervención a los trabajadores en la industria del tabaco en todo lo relativo al estudio de sus problemas. Una confirmación global de la estrategia seguida, apelando al cierre de filas en un monento adverso, en "Firmeza, firmeza inquebrantable», Id., V-1935, p. 1. Para los datos sobre los despedidos, véase «En el año 1935», Id., I-1935, p. 1. El ciclo de involución y los presagios, en «Año nuevo y viejas tareas», Ibid., p. S. También, "Rectificación a desgana» y «Reingreso de los despedidos en la Fábcica de Madrid», Id., VII-1935, pp. 1, 13 y 16. 
la empresa, independientemente de su ideología y de su categoría laboral, estimaba que la unidad había de consagrarse en su propio seno y que su existencia como entidad autónoma debía perpetuarse:

«No hay que dudarlo, la Federación se hizo fuerte por haber nacido autónoma (...). Fue necesario que la Federación se creara y se desarrollara autónoma para poder vencer la enorme resistencia de la Compañía y de sus Jefes. Fue necesaria la autonomía para agrupar a todo el personal tabaquero bajo una sola bandera sindical (...) y que no ocurriera lo que en otras organizaciones, que cuando los de C.N.T. se declaraban en huelga los camaradas de la otra central no la secundaban y viceversa» 56 .

Pero no fueron los cantos a la unidad ni las negociaciones en igual sentido los que hicieron recuperar su vitalidad al sindicalismo tabaquero, vitalidad relativamente perdida tras la represión de octubre del 34. La causa vino dada por la nueva coyuntura política a raíz de la victoria del Frente Popular en las elecciones generales de febrero de 1936. Otra vez, como en 1931, a la Federación Tabaquera se le abría un marco político favorable para desenvolverse con ventaja en la negociación colectiva con la Compañía Arrendataria. Una vez más, también, se podía recuperar el viejo y radical discurso anticapitalista, donde se ponía en cuestión la existencia misma de esa empresa, en tanto que personalizaba una gestión privada del monopolio del tabaco que no tenía razón de ser a ojos de la Federación. Y no tenía razón de ser, no ya por meras cuestiones ideológicas o morales - la economía moral propia del sindicato, se entiende-, que también se blandían como instrumento de ataque a la Compañía (expulsar «al pernicioso intermediarion), sino bajo el argumento supuestamente técnico de que la estatalización generaría mayores rendimientos. Ni que decir tiene que, cuando se hablaba de estatalizar la gestión de la empresa, se daba por supuesto que ello comportaría de inmediato una mayor participación de los trabajadores -es decir, de la Federación- en la toma de decisiones no ya referidas a las fábricas, sino a todo lo que tuviera que ver con la explotación del monopolio. Se trataba, en suma, de resucitar de nuevo el viejo sueño del control obrero.

La primavera y los inicios del verano de 1936 se vieron presididos por ese clima, donde la recuperada arrogancia de la Federación y la creciente radicalización de sus objetivos y exigencias corrieron paralelas a la intranquilidad al alza del personal directivo de la Arrendataria. Por lo pronto, el sindicato consiguió lo que hasta ahora sólo en casos minoritarios había logrado: afiliar en ma-

36 La cita sangrada, en "Discusión entre tabaqueros", Federación Tabaquera Española, VI-I936, pp. 14-15. Las comillas sobre la «central de industria», en $\propto \mathrm{Al}$ presidente del grupo sindical socialista de tabaqueros, de Madtid", Unión Tabacalera, X-1935, p. 13. Para las otras comillas y las divisiones y negociaciones unitatias, en "Por la unificación de los tabaqueros", ld., VII-1935, p. 4, y "Hacia la unidad de los tabaqueros coruñeses" y "Gran asamblea de la Sección madrileña», Id., $\mathrm{X}$ 1935 , p. 5. 
sa a los empleados administrativos y a los técnicos de alta cualificación de la empresa, en muchos casos por vía coercitiva, aunque en su propaganda se presentase esa captación como fruto de decisiones voluntarias. Todo aquél que se atrevía a mostrar su disidencia o, simplemente, a no afiliarse corría el riesgo de hacerse acreedor de «sanciones» y «correcciones» por parte de los federados: «es necesario corregir para educar a quienes faltan al compañerismo o pretenden burlarse de los acuerdos de la organización». Luego, el sindicato tabaquero lanzó un ambicioso programa reivindicativo que comprendía desde el establecimiento, por fin, de un sistema de jubilaciones satisfactorio y digno, hasta aumentos sustanciales y genetalizados de jornales; la implantación de la jornada de cuarenta y cuatro horas semanales (la vigente era de 48); la incorporación del numeroso grupo de aprendizas que se encontraban en lista de espera desde hacía años; la indemnización de los represaliados de octubre de 1934; el fortalecimiento de la disciplina de la Federación sobre todas sus secciones, afiliados y todo el personal en general; y, entre otros objetivos menores, el muy significativo acuerdo de dar «el mayor impulso» a "los consejos obreros de fábrica». Organismos éstos que el sindicato creaba — según decía con objeto de aplacar cualquier conato de alarma - "para el estudio de los problemas del trabajo". Claro que, conscientes o no, los dirigentes de la FTE no daban pie a confusión alguna. El comité de la Federación redondeó sus propuestas exigiendo la dimisión de la dirección de la Compañía, con el ya clásico argumento de la mucha incompetencia demostrada en la gestión de la Renta del Tabaco: «La aspiración de desplazar a la Compañía es tan sentida por el personal que solamente espera la consigna para llevarla a cabo». El anhelado sueño colectivista se iba a hacer realidad muy pronto con el estallido de la Guerra Civil en julio de $1936^{57}$.

\section{LAS FÁBRICAS DE TABACOS EN LA GUERRA CIVIL}

La guerra y la subsiguiente división del país trajeron consigo de forma inmediata la escisión de la Arrendataria. Las distintas dependencias de la Compañía quedaron en absoluta incomunicación, lo que creó una dificilísima situación a la sociedad, al quedar aislados entre sí los elementos de producción, distribución y administración. Aparecieron dos direcciones y dos consejos de administración. En la España republicana los órganos directivos operaron en $\mathrm{Ma}$ drid, hasta el traslado del gobierno a Valencia en diciembre de 1936. En las postrimerías de la guerra se trasladarían a Barcelona. Por su parte, la denomi-

37 Cf. «Un proyecto de reajuste incompleto", «Los Administrativos actúan», «Antecedentes», "Los Consejos Obreros de Fábrica», «El Pleno de la Federación Tabaquera Española» y "Quien no tenga actitudes... que dimita", artículos y notas elocuentes recogidas en Federacion Tabaquera Española, VI-1936, Pp. 1, 2, 4, 8-10 y 13, respectivamente.

Hispania, LX/3, núm. 206 (2000) 1067-1126 
nada CAT nacional actuó en Burgos, sede del cuartel general de Franco. La dispersión de los establecimientos fabriles implicó que unos quedaran en territorio de la República y otros bajo control de «los nacionales». De las doce fábricas que la Compañía tenía en funcionamiento en julio de 1936, solamente cuatro se hallaban enclavadas en la zona que desde un primer momento controló Franco (Cádiz, La Coruña, Logroño y Sevilla), aunque a los pocos meses se incorporó la de San Sebastián. Durante más de un año esas cinco fábricas surtieron de tabaco a la zona ocupada por las fuerzas rebeldes; después, la caída de las provincias del Norte puso en manos de la Renta franquista las de Bilbao, Gijón y Santander. En el lado republicano quedaron, pues, la mayoría de los centros de producción, pero el avance de las tropas franquistas ocasionó que paulatinamente éstas fuesen incorporando un mayor número de establecimientos. Al final, en los últimos meses de la guerra, la CAT de la República sólo contó con los centros de Alicante, Madrid, Valencia y Tarragona.

En un principio, los problemas a los que tuvieron que hacer frente ambas administraciones fueron los mismos: la reorganización de los órganos de dirección y la reconstitución de los respectivos consejos de administración; el suministro de materias primas y el mantenimiento de la producción; y la puesta en marcha de planes para asegurar el abastecimiento de los combatientes y de la población civil. Pero como se verá, las dificultades y el desconcierto fueron muy superiores en la zona republicana, con serios obstáculos para su abastecimiento y con una grave quiebra de la autoridad y de la disciplina laboral, ya que las organizaciones obreras, después de incautarse de las fábricas, interfirieron en el desenvolvimiento de la actividad productiva blandiendo la bandera de la revolución. Esta circunstancia resultó determinante para que el monopolio funcionase peor en la Hacienda republicana que en la nacional.

\section{En la España republicana. La utopía revolucionaria y el control obrero}

Al iniciarse las hostilidades y dividirse el país la mayor parte del consejo de administración abandonó Madrid, lo que puso en serio peligro el funcionamiento de la Compañía. Dado el ambiente de desconcierto político y el rápido movimiento de las organizaciones obreras ocupando talleres y fábricas ${ }^{58}$, no es de extrañar que el primer paso lo diese el comité ejecutivo nacional de la Federación Tabaquera Española. A menos de tres semanas de la sublevación militar, sin esperar instrucciones del Ministerio de Hacienda y al margen de toda legalidad, acordó la incautación de la Compañía, lo que se produjo en la mañana del 3 de agosto. La citada incautación la llevaron a cabo los representantes de los Secretariados Técnico-Administrativo, Subalterno, de Expendedores de Tabaco y Timbre, Sanitario y del Cultivo de Tabaco. Estos nombraron una comi-

sB BRICALL (1986). 
sión permanente compuesta por «la camarada» Eulalia Prieto y por «los camaradas» León Izquierdo y Jerónimo Campano, quienes se encargaron desde ese momento de cuantas funciones desempeñaba hasta la fecha el director-gerente Luis de Albacete, que previamente había sido destituido. El comité de la FTE informó de sus acciones al representante del Estado, al que también comunicaron el cese de los dos únicos consejeros que permanecían en sus puestos, José Alvarez Guerra y Juan Lladó Sáchez Blanco. La FTE adujo que los miembros del consejo de administración venían actuando een contra de los intereses del Estado, de los del personal que dedica su esfuerzo a las distintas actividades de la Renta, y, en algunos casos, en contra de sus accionistas». El comité también pidió que el Estado se incautase «de cuantas acciones de la citada Compañía era propietario el traidor Juan March y las de la familia Urquijom, y que el Ministerio de Hacienda pusiera a disposición de los integrantes de la comisión permanente las cuentas y créditos bancarios de la sociedad. Añadían que el comité deseaba una estrecha colaboración con la Representación del Estado, con «la seguridad de que todo nuestro programa de reorganización, modernización e incrementación (sic) de la industria será cumplido con el mayor entusiasmo». La nota concluía:

\footnotetext{
«En nombre de la República democrática y de las libertades que le son inherentes, esperamos de ese Ministerio apruebe nuestra actitud y nos apoye en nuestros sinceros y vehementes deseos de beneficiar al tégimen y a cuantos españoles son afectados por nuestras actividades. Mucha salud, libertad y Repúblicas 59 .
}

Ante la toma del poder por los representantes sindicales, el Ministerio de Hacienda reaccionó con rapidez, tratando de neutralizar las acciones emprendidas por la FTE y defendiendo sus propios intereses, que se veían claramente amenazados al temerse una verdadera quiebra de la producción y del sistema de distribución del tabaco. En consecuencia, el gobierno hubo de tomar una serie de medidas provisionales para asegurar el funcionamiento de la sociedad y dar respuesta a la FTE. La primera fue un decreto de 4 de agosto de 1936, firmado por el ministro de Hacienda, Enrique Ramos, por el que quedaron destituidos de sus cargos el presidente, Luis de Urquijo y Ussía, y los consejeros Valentín Céspedes, Miguel Tacó y Calderón, José Alvarez Guerra, José García Sánchez, Alfredo Zavala Lafora, Ramón del Rivero Miranda y Francisco Aritio Gómez. Al mismo tiempo se nombraba en sustitución de los anteriores a Amós Salvador Carreras, que actuaría en funciones de presidente, y se reponía en su puesto a Juan Lladó Sánchez Blanco, en representación de los accionistas de la sociedad. El consejo se completaba con funcionarios del Estado, con un representante que debía designar el gobernador del Banco de España, otro de los

99 Secretaría del Consejo: Acra del Comité Ejecutivo Nacional de la Federación Tabaquera Española, de 3 de agosto de 1936, relaciva a la incautación por la misma de la Compañía.

Hispanja, LX/3, núm. 206 (2000) 1067-1126 
obreros de las fábricas y depósitos de tabaco y un empleado de la Compañía elegido por los trabajadores. Por lo demás, el consejo gozaría de las atribuciones consignadas en el convenio de 19 de julio de 1921. Con esto se quiso satisfacer parcialmente las pretensiones de la FTE, pero manteniendo la legalidad y los órganos normales de dirección. No obstante, aunque el gobierno no admitió la existencia del comité como órgano que sustituyese al consejo de administración, ni accedió a la transmisión de poderes financieros que pretendía, no pudo impedir que aquél continuase en funcionamiento. En consecuencia, los nombramientos del Ministerio no surtieron ningún efecto ${ }^{60}$.

Ante el éxito del alzamiento rebelde y el desarrollo de los acontecimientos en Madrid, el nuevo ministro de Hacienda, Juan Negrín, decidió tomar la iniciativa. Así se explica el decreto de 23 de septiembre de 1936, por el que el Estado se incautaba la Compañía Arrendataria, incluyendo sus dependencias centrales, fábricas, depósitos y existencias. La administración de la CAT pasaba a cargo de un comité de gerencia, integrado por obreros y empleados de la empresa designados por las organizaciones sindicales pertenecientes al Frente Popular. La Representación del Estado, encabezada por Arturo Fernández Noguera, conservaba las atribuciones que le asignaba el contrato de $1921^{61}$. El comité de gerencia quedó constituido por doce vocales: José Rodríguez Polo y Jerónimo Campano Fernández, por los empleados administrativos; Eulalia Prieto e Isabel Sarriá, por las operarias; Eduardo Sanjuán, por los tabaqueros de Canarias; Juan Cabañas Soler y Joaquín Salgado Llorente, por los mecánicos; León Izquierdo de la Guida, por los obreros; José Sánchez Bellón y Mercedes Navas Ibáñez, por los expendedores; Olegario Andrés Pablos, por los funcionarios del Resguardo; y Santiago Donoso, por el Servicio de cultivo de tabaco. En la nueva directiva seis miembros pertenecían a la UGT y cinco a la CNT. La primera decisión del recién designado comité fue suprimir la direccióngerencia, sustituyéndola por el cargo de secretario de industria, y las dos subdirecciones, que fueron reemplazadas por una jefatura de sección técnica y otra administrativa. Como presidente y secretario del comité fueron elegidos Rodríguez Polo y Sanjuán (sustituido a los pocos días por Sánchez Bellón) respectivamente, mientras que Campano fue nombrado para el puesto de secretario de industria, e Izquierdo de la Guida para el de vicesecretario. El segundo acuerdo fue una subida lineal de sueldo hasta 4.000 pesetas a todo el personal de oficinas centrales, dependencias, fábricas y depósitos, que cobrase menos de esa cantidad. Por lo demás, la marcha del gobierno de Madrid a la ciudad de Va-

60 El decreto, refrendado por el presidente del gobierno, Manuel Azaña, se insertó en la Gaceta de Madrid, $n^{\circ}$ 218, 5 de agosto de 1936. También, Secretaría del Consejo, "Reunión del Cornité provisional de Adrainistración, celebrada el día 6 de agosto de 1936». La FTE se integró en VGT en Septiembre de 1936, pero corno consecuencia de la crisis sufrida por esta central sindical el año siguiente la FTE fue una de las federaciones de industria expulsadas en septiembre de 1937. Cf. ROMERO MASIA (2000), p. 496 y ss.

61 Gaceta de Madrid, n 268, 24 de septiembre de 1936. 
lencia, el 20 de noviembre, supuso el traslado de las oficinas centrales de la Administración del Estado y por ende de la sede social de la Compañía y de su recién formado comité de gerencia ${ }^{62}$.

La composición del comité emponzoñó de forma continua la vida administrativa de la sociedad, particularmente en todo lo relativo a las relaciones laborales. Además, nunco logró un control de la Compañía, en la que los consejos obreros de las fábricas y los sindicatos tabaqueros se hicieron con el mando efectivo de las secciones de producción y distribución. Desde Valencia resultó difícil que las órdenes llegasen y se acatasen en las distintas dependencias incluidas las de Madrid- - que la Arrendataria tenía esparcidas por todo el territorio de la península, más aún dada la precariedad de las comunicaciones y el ambiente de indisciplina laboral reinante en la España republicana durante el primer año y medio de guerra. El primer enfrentamiento surgió cuando el Ministerio de Hacienda ordenó el desplazamiento de servicios y funcionarios a Valencia, con excepción de aquéllos que fueran imprescindibles para mantener con un mínimo de operatividad las dependencias centrales. Entre el personal de Madrid se levantó una notable resistencia a acatar lo mandado; tampoco el comité de gerencia, ni los sindicatos, en particular la CNT, se mostraron entusiasmados. El grado de incumplimiento debió de ser preocupante, pues al poco tiempo la Representación del Estado conminó a la Compañía para que determinara el número de funcionarios imprescindibles en Madrid (exclusivamente el personal necesario para la custodia y conservación del edificio) y destinase a todos los demás a cubrir la plantilla de Valencia, añadiendo que: «si los funcionarios trasladados no se personasen en sus nuevos destinos dentro del plazo posesorio (sic), serán dados de baja automáticamente en los respectivos escalafones” ${ }^{63}$.

En una sesión extraordinaria del comité de gerencia celebrada en Valencia el 28 de enero de 1937, el secretario de industria informó de la comunicación recibida de la Dirección General del Timbre y Monopolios, en la que se hacía constar que: «algunos funcionatios de la Compañía se niegan a cumplir las órdenes de traslado a Valencia... [y] Ha sabido, igualmente, que se impide la salida de documentación necesaria para la buena marcha de la Renta». Campano calificó el hecho de manifiesta indisciplina y leyó una carta del Sindicato

62. El decreto, dado en Valencia y firmado por Juan Negrín, se publicó en la Gaceta de la Repkiblica, $\mathrm{n}^{\circ} 336,1$ de diciembre de 1936. En cuanto a los antiguos subdirectores, Calvo Rodero y Rojas Rubio, el comité decidió separarlos de sus puestos (ACG, 15-XII-1936). En Madrid, a cargo de la dirección de las oficinas, quedó Castor Calvo Rodero (Archivo CAT, leg. 998, libro 1).

63 Orden del Ministerio de Hacienda de 14 de abril de 1937. El incumplimiento debió ser bastante general, pues el Ministerio de Hacienda tuvo que reiterar la orden de traslado de funcionarios y las sanciones que implicaba su incumplimiento (Orden del M. de Hacienda de 13 de sepriembre de 1937). Cuando el craslado de empleados hacia Valencia no había concluido, se inició desde noviembre de 1937 uno nuevo hacia Barcelona. Asimismo, a principios de enero de 1938 se prepararon los planes para la evacuación definitiva de todos los empleados de la Renta que aún quedaban en Madrid (Oficio de 6 de enero de 1938, Archivo CAT). 
Unico de la Industria del Tabaco, afecto a la CNT, que en su asamblea general de diciembre había aprobado que se impidiera la salida de cualquier funcionario de la capital. Miembros de la CNT también habían realizado gestiones con el propio ministro de Hacienda tratando de obligarle a que los servicios de las oficinas centrales de la Compañía regresasen a la capital. Rodríguez Polo, presidente del comité y miembro de la CNT, confirmó la reunión con el ministro, a la que también asistió Federica Montseny, ministra de Sanidad, aduciendo que más que «indisciplina» se había producido una "errónea interpretación» de las órdenes. La desobediencia no era exclusiva de los afiliados de la CNT, sino que también obreros de la UGT de la fábrica de Madrid se habían opuesto al traslado a Valencia. Arturo Fernández Noguera, como representante del Estado, insistió en que el personal que permaneciese en Madrid pasaría a situación de disponible forzoso, quedando a disposición de la Junta Delegada de la Defensa de Madrid. Pero en sesiones posteriores este asunto volvió a debatirse, dado el manifiesto incumplimiento de las órdenes, lo que dio lugar a diversos enfrentamientos entre los representantes de la CNT y de la UGT en el seno del comité. Al final, el Ministerio tomó la resolución de cesar y declarar desafectos a los funcionarios que se negasen a cumplir la orden de traslado, pero como la mayoría de ellos pertenecía o se había alistado a la CNT, los miembros de este sindicato en el comité protestaron la determinación del gobierno ${ }^{64}$.

La interferencia de los sindicatos en materia de nombramientos y ceses del personal también incidio en la efectividad del comité. Las disensiones alcanzaron su punto culminante cuando el comité nacional de los Sindicatos de Industria del Tabaco aprobó una serie de resoluciones contra decisiones del secretario de industria y del propio comité de gerencia. Campano había cesado a diversos empleados que pertenecían a la CNT y ésta lo había tomado como un ataque al sindicato y un desafio a su posición y poder dentro de la Compañía. Sánchez Bellón insistió que el secretario de industria había procedido contra varios trabajadores por motivos personales y por su oposición a la Federación Tabaquera Española. El secretario de industria se defendió reiterando que le correspondían todas las competencias que antes tenía asignadas la dirección-gerencia de acuerdo con los Estatutos de la Compañía ${ }^{65}$. Otto asunto que consumió largas e infructuosas horas de debate en el comité de gerencia, fue la pretensión del cenetista comité nacional de los Sindicatos Unicos de la Industria Tabaquera de sustituir a sus miembros en el seno del propio comité al margen de los procedimientos estatutarios ${ }^{66}$. El comité de gerencia nunco quiso admitir que la CNT, por su cuenta y riesgo, sustituyese y nombrase nuevos miembros; tam-

64 ACG, 28-I-1937 y $25-$ II- 1937

6 ACG, 1-V-1937.

66 Paradojicamente, continuaban en vigor los que regian para el antiguo Consejo de Administración (cláusula 52 del Convenio con el Estado). 
poco el Ministerio de Hacienda ${ }^{67}$, que reiteraba que en lo relativo a nombramientos y sustituciones de los componentes del comité de gerencia debía procederse conforme a lo prevenido en el contrato con el Estado, y a tal efecto se expidió la correspondiente orden ministerial. No obstante, el comité de los Sindicatos Unicos se mostró disconforme y recurrió la resolución ${ }^{68}$.

La cuestión de las depuraciones también envenenó el ambiente. Por lo general carecieron de control, llevándolas a cabo las distintas secciones de los autodenominados comités del Frente Popular Tabaquero, que actuaban de forma casi independiente en cada una de las dependencias y fábricas. Se depuró al personal directivo, por supuesto, pero también a todos aquellos que en el pasado habían manifestado una ideología política contraria al Frente Popular, o habían adoptado una actitud antisindical. También a los llamados «quintacolumnistas": los sospechosos de colaborar directa o indirectamente en «la creación de un estado de ánimo o de opinión contratio a la revolución» ${ }^{69}$.

Mientras tanto, desde los primeros meses después de la rebelión del 18 de julio, la organización de las fábricas se fue deteriorando. La autoridad se debilitó hasta casi desaparecer y se quebró la jerarquía de mando. En todos los establecimientos productivos se formaron comités o consejos obreros de control que fueron paulatinamente incrementando su poder y su intervención en la administración de las fábricas, no sólo en todo los relacionado a organización de servicios y trabajo, sino también en asuntos puramente administrativos y financieros. Su creación se realizó de forma irregular, sin acuerdo de los comités de empresas, ni orden oficial que dispusiera y reglamentara su constitución y funcionamiento. Además, no todos los que se formaron siguieron una misma pauta de actuación, pues mientras en algunas fábricas llegaron de forma inmediata a hacerse cargo de la dirección, en otras la actuación fue más moderada. En todo caso, el proceder de los consejos generó, durante los primeros meses, una situación que sin duda merecería el calificativo de caótica. Las circunstancias llegaton a tal extremo de confusión que el propio comité de gerencia se propuso rectificar y clarificar las competencias de los consejos. Asimismo, se redactaron unas instrucciones en un vano intento por reglamentar sus anárquicas actuaciones. En ellas se señalaba que el comité obrero estaría formado por representantes de los obreros de cada taller y explícitamente admitía que: "controla la marcha de la fábrica, y por tanto intervendrá conjuntamente con el delegado administrativo en todos los asuntos de índole social, de trabajo o de organización de servicios que afectan al régimen interior de la fábrica». En el fondo lo que estas instrucciones pretendían era reservar al jefe del establecimiento, al menos, las competencias administrativas y financieras y que en caso

67 ACG, 17-V-1937. Las sustituciones afectaban a cuatro de los cinco miembros de la CNT (Rodríguez Polo, Salgado Lorente, Satrió y Sánchez Bellón). La UGT disponía de seis miembros.

6в ACG, 29-VI-1937. El asunto volvió luego al Ministerio y también a una nueva reunión del comité de gerencia, que en votación rechazó las pretensiones de la CNT' (ACG, 21-VIII-1937).

69 ACG, 15-XII-1936. 
de conflicto entre ambas instancias las discrepancias se elevasen a la "central». Pero tal estrategia sirvió de poco, ya que hasta principios de 1937 los comités obreros prácticamente tomaron en sus manos la dirección de los asuntos de las fábricas del Monopolio. Aparecieron nuevos consejos que acabaron interviniéndolo todo, firmando con los jefes de fábrica hasta la correspondencia mercantil y administrativa. De hecho, implantaron un modelo de gestión asamblearia. Otros, sin embargo, decayeron rápidamente en su actuación, concentrándose en los aspectos puramente laborales. En una tentativa posterior de normalizar la conducta de los consejos obreros, la Representación del Estado llevó a cabo diversas consultas con el llamado comité nacional de la industria tabaquera (CNT-UGT), conviniéndose que cada consejo de fábrica estaría compuesto de tres obreros, cuya misión sería proponer la mejor forma de dar impulso y perfeccionar la producción así como velar por la disciplina laboral.

La red de distribución - los estancos- - también atrajo la atención de los sindicatos obreros y de las organizaciones revolucionarias. Aprovechando el desconcierto general, organismos sindicales y políticos de toda índole procedieron a la incautación sistemática de las expendedurías, apropiándose de las existencias y del capital invertido. Los motivos de tales actos fueron eminentemente políticos, desposeyendo de su concesión a aquéllos elementos que las citadas organizaciones consideraban desafectos al régimen, lo que en muchos casos simplemente significaba que habían sido fieles representantes de la Arrendataria. El fenómeno parece que alcanzó a un buen número de estancos en la práctica totalidad de las provincias leales a la República. Frente a las incautaciones, la Representación del Estado reaccionó ordenando el cese inmediato de la apropiación de los estancos; pero, sin medios para impedirlo, las incautaciones continuaron. También hubo de reiterarse que la política de provisión de vacantes de las expendedurías no se había alterado, por lo que la Compañía debía cubrir las que existiesen en la forma acostumbrada, o administrarlas directamente por medio de sus empleados. Con mucho retraso y a la vista de que la situación no se enderezaba, el Ministerio de Hacienda resolvió tomar cartas en el asunto. Hacia mediados de 1937 dictó una serie de órdenes pidiendo a la Compañía que procediera al rescate de cuantas expendedurías estuviesen incautadas, restituyéndolas a sus legítimos titulares, caso de existir y no haber sido privados de sus derechos, e incluyendo en la devolución las existencias, el capital invertido y los beneficios obtenidos. Aunque sabemos que el comité de gerencia trasladó los oportunos oficios a las dependencias afectadas, no resulta fácil conocer el grado de acatamiento de lo ordenado ni el número de expendedurías afectadas. Sin embargo, lo que sí sabemos es que en esas fechas la CNT proseguía con nuevas incautaciones desoyendo el mandato y los deseos del Ministerio de Hacienda y del Monopolio ${ }^{70}$.

70 De no encontrarse el titular del establecimiento, éste debía precintarse y sus existeacias y fondos ponerlos a disposición de la DGTM (Oficio de la Representación del Estado de 4 de sep- 
$\mathrm{Ni}$ que decir tiene que todas las circunstancias relatadas condicionaron y restaron eficacia al sistema de producción y a los mecanismos de distribución de la industria tabaquera. Las consecuencias se percibieron de inmediato: desorganización laboral, dificultades en el aprovisionamiento de materias primas, caída en picado de los rendimientos y de la calidad del producto, racionamiento del tabaco en las fuerzas combatientes y en la población civil, caos distributivo, favoritismo y corrupción en las ventas y pagos de suministros, disminución en la capacidad recaudatoria del Ministerio de Hacienda, etc. Las autoridades republicanas tardaron más de un año en admitir explícitamente los problemas creados por la acuciante escasez de tabaco, consecuencia de las dificultades de aprovisionamiento, de la desorganización y de los procesos revolucionarios ensayados en las fábricas. En realidad, este estado de cosas duró, de forma más o menos acusada, hasta abril de 1938, cuando el Estado tomó a su cargo la administración directa de la industria tabaquera con un decreto emitido el día 29. Arturo Fernández Noguera, como director general del Timbre y Monopolios, se hizo personalmente cargo de la Renta de Tabacos y, como nuevo responsable directo, dispuso la disolución del comité de gerencia y el cese fulminante de los empleados y obreros que lo componían. Asimismo, ordenó la inmediata convocatoria de la junta de accionistas de la Compañía con objeto de que se nombrara la correspondiente comisión liquidadora. La representación obrera en el nuevo consejo de administración se redujo notablemente: obreros y empleados ocuparon solamente cuatro vocalías, dos para la UGT y dos para la CNT; también se designó un vocal por los cultivadores de tabaco y otro por los empleados del ramo de cerillas ${ }^{71}$.

Con la recomposición de los órganos ejecutivos de dirección y control del Monopolio, se persiguió deshacer el desastroso camino andado desde el inicio de la guerra en las dependencias centrales y en las fábricas. $O$ lo que es lo mismo, invertir el proceso revolucionario. Así ha de entenderse, por ejemplo, que en el citado decreto de abril de 1938 y en posteriores resoluciones ministeriales no se admitiese en ninguno de sus artículos - $\mathrm{e}$ incluso se prohibiese taxativamentela existencia de los consejos de fábrica y la intervención de la representación sindical fuera de los puestos que se les asignaron en el consejo de administración. En la misma línea se actuó de forma enérgica en otra de las áreas en las que se había producido un total desbarajuste: la distribución del tabaco. En definitiva, se pretendió dar un giro de ciento ochenta grados a la situación creada en los dos años anteriores. No obstante, los derroteros recorridos se revelaron imposibles de enderezar en el tiempo que quedaba hasta el final de la guerra. Cuando las autoridades republicanas quisieron corregir la situación, ya era demasiado tarde. En abril de 1939 la guerra había terminado y con ella el sueño colectivista por el

tiembre de 1937 y Oficio de la DGTM de 9 de febrero de 1938, Archivo CAT, Secretaría). Cf. también el oficio de la Representación del Estado de 18 de febrero de 1937 (Archivo CAT, Secretaría) y ACG, 18-VIII-I 937 y 7 -IX-1937.

${ }_{71}$ Oficios de la DGMM, 2 de mayo y 16 de noviembre de 1938 (Archivo Tab., Secretaría). 
que tanto lucharon muchas cigarteras durante generaciones y los sindicalistas de la Federación Tabaquera en particular ${ }^{72}$.

En la España insurgente. Colaboracionismo, depuración y condiciones de trabajo

La evolución de las relaciones de trabajo en las fábricas y depósitos de tabaco situados en la España «nacional» nada tuvo que ver con la que se ha descrito para las dependencias ubicadas en la zona republicana. Desde el primer momento, cualquier conato de resistencia obrera fue apagado contundentemente. Incluso allí donde meses antes había organizada una poderosa fuerza sindical - fábricas como las de Cádiz, Sevilla o La Coruña - fue impuesta de inmediato y sin grandes problemas la más férrea disciplina sobre los trabajadores. Se destruyeron redes asociativas que contaban con una larga tradición detrás; se depuró, eliminó o encarceló a los cuadros dirigentes; se cerraron los locales de los sindicatos; se acallaron las voces de protesta y se establecieron unas condiciones de trabajo más duras, acordes con las necesidades de la guerra y factibles por la desarticulación de las sociedades obreras. La sumisión, la diciplina y el encuadramiento pretoriano del personal de las fábricas fue así la consecuencia instantánea de la temprana derrota del sindicalismo tabaqueto, que se mostró incapaz, como el conjunto del obrerismo, de alentar una contraofensiva capaz de contener la rebelión antirrepublicana en estas provincias ${ }^{73}$.

Coherentes con su identificación de intereses con las autoridades rebeldes, los dirigentes de la Compañía Arrendataria que quedaron en el territorio insurgente -o los que posteriormente lograron pasarse al mismo- se prestaron a colaborar con el nuevo poder. Toda la infraestructura fabril y la estrategia productiva se supeditaron a las necesidades de la guerra, a surtir de tabaco a los ejércitos y a cubrir la demanda de la población. Porque, a efectos propagandísticos, indirectamente también esta última era una forma de combatir y de prestar apoyo a la causa rebelde. De la importancia de la propaganda y de la voluntad de mímesis con la rebelión --más allá de la estrategia productiva- - dan cuenta un sinfín de gestos con fuerte carga simbólica alentados por los gestores de la CAT a lo largo de los casi tres años que duró el conflicto. Aparte de los surtidos habituales, cada dos por tres se hicieron sustanciosos envios gratuitos de tabaco para los soldados; se contribuyó con generosas cantidades al «aguinaldo del combatiente»; se aprobaron partidas de dinero con destino a los heridos de guerra; se pusieron camiones de la empresa a disposición de las autoridades militares alli donde hizo falta; se participó en suscripciones para la elevación de monumentos a los caídos o en

72 Ver también el oficio de la DGTM de 1 de octubre de 1938, Archivo CAT, Secretaría.

73 Al mismo Severino Chacón le pilló el estallido de la guerra en La Coruña y hubo de esconderse durante un año. Para su rocambolesca trayectoria, en paso a la España republicana y su posterior exilio, ver ROMERO MASÍA (2000), pp. 483-560. 
memoria de «insignes patriotas» como José Calvo Sotelo; se suprimieron los emblemas y colores republicanos de las labores de tabaco; se hicieron donativos para el Auxilio Social... Todo, en fin, se supeditó por los responsables de la Arrendataria al esfuerzo bélico y a la causa nacional, opción que sin duda condicionó la trayectoria de la empresa mientras duró el conflicto, como también las vidas y la situación laboral de sus empleados y trabajadores ${ }^{74}$.

La disposición entusiasta de la CAT a colaborar y su generosa identificación con las autoridades rebeldes no pasó desapercibida para éstas últimas, incluido su máximo dirigente, el general Franco. En mayo de 1939, ya liquidado el período bélico, se recibió en la fábrica de tabacos de La Coruña una elocuente carta de la Jefatura del Estado agradeciendo los muchos servicios prestados durante los casi tres años de guetra:

\footnotetext{
"Consecuente a su atento escrito de fecha 29 del pasado abril, tengo el honor de expresar a Vd. en nombre de S. E. el Jefe del Estado y Generalísimo, su agradecimiento por la incesante labor de cooperación que esa prestigiosa entidad viene prestando a la Causa y le ruego dé traslado de esta expresión de S. E. a los miembros que componen su Consejo de Administración»75.
}

La sensibilidad colaboracionista de la CAT no se limitó a las autoridades militares y a las fuerzas combatientes, sus necesidades y sus símbolos. En la guerra se hizo lo que nunca se había hecho en toda la tradición anterior de la empresa, al menos oficialmente, esto es: prestar servicios, y aportar dinero y cooperación a organizaciones políticas concretas, so pretexto, obviamente, de formar parte del aluvión general de eso que se llamaba en términos imprecisos, pero no inocentes, «el Movimiento» (el término "partido» se aborrecía por considerarse subversivo y antinacional). Así, en junio de 1938 el consejo de administración autorizó la inscripción del nombre de la Compañía entre los socios protectores de Acción Española, para la que se aprobaron 500 pesetas en concepto de cuota anual. Esta entidad había funcionado — con su famosa revista y

74 Ingresos de 5.000 pts. para el «aguinaldo del combatiente", en ACAT/ZN, 8-I-1937 y 16XII-1937. Proposición de donativo «a la Señora de su Excelencia el Generalísimo» para los heridos de guerra, en Ibid., 25-VI-1937. Sendos envíos gratuitos de tabaco para las tropas, en lbid., 25-V1937, 29-XI-1937, 11-II-1938. Donativo de 5.000 pts. para las «Milicias Gallegasw, en Ibid. 1XII-1936. Donativo de 25.000 pts. para "Auxilio Social", en 10-XI-1938 y 21-XII-1938. Los camiones, en lbid., 30-Ill-1937. Contribución de 25.000 pes. por la CAT para la elevación de un monumento a los caídos en Burgos, y acuerdo de contribuir con otras 5.000 para erigit un monumento en Tuy al «insigne patriotas José Calvo Sotelo, en lbid., 29-XI-1937. Donativo de 2.000 pts. pata la edición de la obra Mi libro, «del ilustre General Orgaz», en Ibid., 29-IV-1939. La resolución de contribuir a la suscripción abierta en homenaje al «Excmo. Sr. General Mola (q.e.p.d.) con la cantidad máxima señalada en dicha suscripción para las Empresas y que es de 1.000 pesetas", en Ibid., 10-V-1938. Los enblemas republicanos, en ACAT/ZN, 30-VIII-1938.

75 La carta venía suscrita por la Jefatura de la Sección de Donativos de la Jefarura del Estado. Ver ACAT/ZN, 31-V-1939.

Hispania, LX/3, núm. 206 (2000) 1067-1126 
sus medios de propaganda- como baluarte de la oposición monárquica de extrema derecha al régimen republicano en el período previo a 1936. Sus miembros, la mayoría de ellos ideólogos e intelectuales consagrados por su talante abiertamente reaccionario, fueron unos adelantados en la configuración de los principios autoritarios en los que luego se fundamentaría el régimen franquista ${ }^{76}$.

En idéntica línea, se ayudó y se prestó cooperación a la Falange y a sus intereses. Contando con el visto bueno de la Representación del Estado en la Compañía, y a requerimiento del citado partido político, también en el verano de 1938 la CAT se avino de forma complaciente a utilizar su engranaje comercial y su red de expendedurías para la venta de un sello de José Antonio Primo de Rivera, cuya recaudación se destinaría «al subsidio pro-combatientes, entendiéndose directamente la Junta que lo administra con los expendedores ${ }^{77}$. Más de una expendeduría se proveyó, además, siguiendo las sugerencias de la organización falangista. Pero en este campo, la CAT, aun plegándose a las servidumbres de la guerra, procuró que su capacidad de decisión no se viera mermada en exceso por los intereses de las entidades partidistas del Movimiento, crecidas en sus aspiraciones al hilo de las circunstancias y deseosas de aprovecharlas para imponer a empresas como la Arrendataria sus directrices a efectos de su propia rentabilidad política. Así, por ejemplo, cuando en septiembre de 1937 F.E.T. de las J.O.N.S. de Pamplona solicitó la instalación de una fábrica de tabacos en la capital navarra, la ejecutiva de la Arrendataria le contestó saliéndose por la tangente y haciéndole ver: «la imposibilidad de poder acceder en estos momentos a su petición'». Del mismo modo, a mediados de 1938, la Delegada Nacional de Asistencia a Frentes y Hospitales de Falange presentó una instancia en la pretensión de controlar la provisión del servicio de expendedurías de los frentes, pero la CAT rechazó esa posibilidad escudándose en la normativa que regulaba el funcionamiento y la provisión de la red de expendedurías. Lo que bajo ningún concepto deseaban los gestores de la empresa era ver recortadas sus atribuciones. De todas formas, la tendencia de los acontecimientos fue en esa dirección, que la postguerra se iba a encargar de reforzar. El nuevo poder necesitaba construir sus propias redes clientelares, y eso lo hizo de acuerdo a criterios políticos que no se dudó en anteponer a los de la Compañía Arrendataria ${ }^{78}$.

\footnotetext{
76 La procección a Acción Española, en ACAT/ZN, 30-VI-1938.

7 ACAT/ZN, 30-VI-1938 y 9-VII-1938.

78 Toda esta argumentación se apoya en ejemplos y datos tomados de ACAT/ZN, 12-VI$1937,10-\mathrm{X}-1937,10-\mathrm{VI}-1938$ y $30-\mathrm{IX}-1938$. Se trataba, evidentemente, de guardar al menos las formas, para que no diera la sensación de que las decisiones de los gobernantes tenían carácter de imposición. Pero, de hecho, la CAT acababa plegándose - y lo seguiría haciendo- a lo que las nuevas autoridades políticas y militares le indícaban. Verdaderamente, su autonomía se vio drásticamente recortada por las nuevas circunstancias y el nuevo entramado de poder que la guerra edific6. Desde finales de 1938, por citar otro hecho relevante, el mismísimo general Millán Astray,
} 
En el ámbito estrictamente laboral, las interferencias de la guerra también se dejaron notar. Como es lógico, una circunstancia tan excepcional pesó en muchos sentidos sobre la marcha de las fábricas y su personal, obstruyendo a menudo el funcionamiento normal de los trabajos. En San Sebastián, por ejemplo, a requerimiento de la autoridad militar hubo que habilitar en noviembre de 1937 parte de los almacenes para montar un improvisado hospital. Por su parte, la fábrica de Bilbao quedó imposibilitada para funcionar por sólo contar con unos cincuenta operatios; razón por la cual se cerró y su personal fue trasladado a otras fábricas. Además, el acoplamiento improvisado en las dependencias disponibles de empleados, técnicos o trabajadores que venían huyendo de la zona republicana se halló a la orden del día. Del mismo modo, cuando se ocuparon ciudades con fábricas de tabacos que inicialmente habían estado situadas en territorio enemigo, fue preciso contratar nuevo personal para cubrir las vacantes dejadas por los trabajadores afines a la causa de la República y, sobre todo, asegurarse la fidelidad de los que se habían quedado. Esto último se hizo recurriendo a una política de depuración extremadamente implacable. Por su lado, los sucesivos decretos movilizando nuevas tropas también ocasionaron perjuicios serios, porque con frecuencia afectaban a individuos (ingenieros, mecánicos...) cuya cualificación resultaba indispensable para el mantenimiento de los niveles productivos que, por otra parte, exigían las autoridades políticas. En estos casos, la Compañía se esforzaba en lograr para ese personal algún régimen de excepcionalidad que hiciera compatible la prestación del servicio militar con el mantenimiento de sus funciones dentro de la empresa ${ }^{79}$.

Donde, sin embargo, se apreció más nítidamente el vuelco que había dado la situación fue en la radical desaparición de todo conato de movimiento sindical y en la instauración de un régimen de trabajo durísimo, propio de una economía de guerra, donde la opinión de los asalariados no se tuvo para nada en cuenta, entre otras causas porque apenas se manifestó por razones obvias. En las fábricas tabaqueras de la zona llamada nacional, a partir de julio de 1936, no existió ni una sola condición favorable al planteamiento de reivindicaciones obreras. El otrora muy poderoso sindicalismo tabaquero vio bruscamente cortadas sus actividades de la noche a la mañana, disolviéndose su organización como por ensalmo. La actividad sindical se redujo a cero y no se tiene constan-

antaño fundador de la Legión y ahora en calidad de director del «Benemérito Cuerpo de Mutilados de Guerran, estuvo encima de la Compañía Arrendataria para que las expendedurías o cualquier tipo de puestos que pudieran crearse se reservasen preferentemente: «a los solicitantes, viudas, huérfanos o próximos familiares de militares, marinos o personas muertas gloriosamente en defensa de nuestra Santa Causa o víctimas de los desmanes y crímenes marxistas». En su deseo explícito de controlar la política de provisión de plazas pidió, igualmente, intervenir de manera directa en la tramitación y fallo de los expedientes de depuración de los empleados y obreros de la empresa (ACAT/ZN, 19-XI-1938 y 29-IV-1939).

79 Lo de San Sebascián, en ACAT/ZN, 11-XI-1937. Lo de Bilbao, en lbid., 11-IX-1937. Un ejemplo de personal cualificado para el que se demanda un crato especial, en Ibid., 22-IX-1937.

Hisparia, LX/3, núm. $206(2000) 1067-1126$ 
cia de que hubiera el más mínimo atisbo de resistencia a la rebelión desde el específico ámbito del mundo del tabaco. Los síntomas que en este sentido pudieron detectarse se extirparon con rapidez, dejando constancia de ello a la autoridad militar de la plaza en cuestión, que se encargó de tomar las medidas represivas oportunas ${ }^{80}$.

La purga de los trabajadores se puso en marcha al instante tras estallar la rebelión militar. Cuando el 5 de diciembre la Junta Nacional de Defensa promulgó un decreto fijando las normas para depurar al funcionariado, la Compañía, aunque su personal en sentido estricto no reunía esa condición, se avino en seguida a aplicarlo. La intranquilidad pasada por los responsables de la empresa en los meses transcurridos después de la victoria del Frente Popular se hallaba presente, desde luego, tras esa actitud. Si no, resulta difícil explicar por qué se prestaron con tanto celo a las tareas depuradoras y alentaron a su personal de confianza a esmerarse en el mismo sentido. Lo refleja, por ejemplo, este acuerdo suscrito en una reunión del consejo de administración celebrada, paradójicamente, el 14 de abril de 1937:

«A propuesta del Señor Presidente del Consejo de Administración, éste acuerda que se dirija a los Señores Administradores Jefes de Fábricas y Representantes provinciales una circular en la que se les estimule a la depuración del personal que de ellos dependan, haciéndoles responsables de que en el mencionado personal no se hallen empleados ni obreros que puedan tacharse de no ser afectos al movimiento liberador ${ }^{81}$.

Para mejor realizar la política depuradora se requirió el auxilio de las autoridades, de las que, a su vez, se recabó información sobre la filiación política y sindical de los afectados. Cuando iban cayendo las ciudades republicanas, el personal técnico, administrativo u obrero de las fábricas, depósitos y representaciones de tabaco, así como los expendedores, rápidamente resultaban depurados. El primer paso era la suspensión de empleo y sueldo de todo el personal dependiente de la Compañía, suspensión que hasta que no se fallase en contra, en su caso, no se levantaba. Todo el mundo era considerado a priori sospechoso mientras no se demostrase lo contrario una vez efectuada la correspondiente investigación. Pero la depuración específica de la Compañía se detenía en los

so En marzo de 1937 se instruyó un expectiente en la fábrica de San Sebastián con motivo del hallazgo de unos dibujos alusivos a José Antonio Primo de Rivera, poniéadose en conocimiento de la autoridad competente para hallar a los autores. El detalle es un signo evidente de oposición soterrada, por insignificante que pueda considerarse (ACAT/ZN, 11-III-1937). En abril de ese mismo año se abrió una información en la creencia de que se cotizaba para la CNT en un bar sicuado frente a la fábrica de La Coruña (Ibid., 14-IV-1937). Ejemplos de operarios que son multados y expulsados de las fábricas por manifestar simpatías hacia la República o hacer comentarios desfavorables al "movimiento nacional", en Ibid., 14-IV-1937, 12-V-1937 y 12-VI-1937.

81 Lo del decreto, en ACAT/ZN, 16-XII-1936. La circular, en Ibid., 14-IV-1937. 
casos en que el correspondiente tribunal militar tenía algo que decir, al que se subordinaba cualquier tipo de acción o expediente abierto a los trabajadores. Cuando, por ejemplo, se advertía que algunos o muchos trabajadores habían prestado servicio de armas a favor del «ejército rojo», se paralizaba toda resolución en tanto la autoridad militar dictaminase si por tales hechos quedaban sometidos a algún procedimiento judicial. Si el dictamen militar era inculpador, la Compañía hacía lo propio expulsando de la empresa en el acto a los afectados. La mera no presentación al trabajo, pasados diez dias tras la «liberación» de una plaza donde hubiera dependencias o fábricas de la CAT, conllevaba también la pérdida del empleo. Como también era más que sospechoso y negativo el hecho de haberse trasladado de fábrica conforme avanzaban las tropas nacionales ${ }^{82}$.

Todos los represaliados a partir de entonces lo pasaron verdaderamente $\mathrm{mal}$, en particular aquellos que perdieton su empleo o los derechos que les correspondían a perpetuidad. Con los «desafectos» no se hizo excepción alguna, ni siquiera con los asalariados ancianos que venían percibiendo una jubilación o con las mujeres embarazadas, que por esa condición tenían acceso legal al seguro de maternidad ${ }^{83}$. Pero más allá de la represión, la guerra también afectó negativamente en muchos sentidos al conjunto de la masa laboral. Por ejemplo, si hubo que producir labores de tabaco para enviarlas gratuitamente a las tropas combatientes, se invitó al personal obrero de las fábricas a realizar su elaboración «en horas extraordinarias sin percibir retribución alguna». Muchas veces fueron los propios trabajadores los que, dando muestra de un manifiesto servilismo acorde con el momento, se ofrecieron, individual o colectivamente,

82 Depuración en las expendedurías, en ACAT/ZN, 29-IV-1937. Un ejemplo de suspensión preventiva de empleo y sueldo, en lbid., 20-VIII-1937 y 11 y 22-IX-1937. En Santander la Delegación de Orden Público, previo expediente abierto por el administrador-jefe de la fábrica, expulsó del trabajo a 43 obreros considerados desafectos (lbid., 10-X-1938). Pata Logroño, lbid., 11-IX-1937. Datos y nombres sobre la depuración en la fábrica de Bilbao, en lbid., 10-X-1937. La depuración en Tartagona, en Ibid., 20-I-1939. La no readmisión de obreros no presentados en el plazo estipulado, en lbid., 10-VIII-1938. Lo de los trabajadores castigados por no haber permanecido en su fábrica y en su ciudad a la espera de la entrada de las tropas "nacionales", por ejemplo, en el caso de Valencia (Ibid., 29-IV-1939), donde todos los obreros procedentes de las fábricas de San Sebastián, Bilbao, Santandex, Gijón y Tarragona que allí había fueron instantáneamente dados de baja. A los procedentes de Madrid se les abrió expediente, hasta dar un fallo; trato diferenciado seguramence debido al hecho de que su traslado había sido impuesto en su día por las autoridades republicanas. Con todo, durante la guerra, en algunos casos se hicieron excepciones en el sentido de no aplicar el principio de suspensión de empleo y sueldo en tanto no se hubiesen instruido los expedientes de depuración. Eso ocurrió cuando fueron «liberadas" ciudades en cuyas fábricas escaseaba el personal. Ahora bien, con los trabajadores cuya desafección se hallaba completamente comprobada ni siquiera en tales circunstancias se hicieron excepciones (las oriencaciones al respecto del consejo de administración, en ACAT/ZN, 31-III-1938).

${ }^{83}$ Ejemplo de oficial adminisrrarivo jubilado que pierde su pensión por ser procesado y declarado desafecto, en ACAT/29-XI-1937. La embarazada, en Ibid., 30-IX-1937. 
para trabajar gratis en circunstancias semejantes. Otros, para satisfacción de la empresa, llegaron a renunciar al disfrute de la licencia quincenal de vacaciones retribuidas a que tenían derecho anualmente, «deseando sacrificarse por España en la medida de sus posibilidades ${ }^{84}$. Además de aquellos ofrecimientos extraordinarios, la sobreproducción que hubieron de encarar las fábricas tabaqueras redundó en un considerable empeoramiento de las condiciones laborales de todos los asalariados: se intensificó el ritmo de trabajo; se multiplicaron los turnos; se reubicó o se trasladó de fábrica a muchos obreros sin tener apenas en cuenta los costes personales que pudieran darse; se trabajaron los días festivos, e incluso se tiró por tierra la conquista histórica de las ocho horas, que pasó a ser de diez sin apelación posible ${ }^{85}$.

Pero lo peor de todo, al menos para aquellos que habían alimentado una conciencia sindical en los años previos y militado en la Federación Tabaquera o en cualesquiera otra organización laboral, debió ser el encuadramiento cuasi militar a que se vieron sometidos fuera y dentro del trabajo. Aparte de las periódicas interferencias de las autoridades militares que se han referido, o de la actitud beligerante de la propia empresa hacia muchos de sus empleados, la Falange también se mostró dispuesta a meter en cintura a los trabajadores del

94 Las primeras comillas, en ACAT/ZN, 14-IV-1937. Fil sacrificio por España, en lbid., 19-XI1938. En una fecha tan temprana como octubre de 1936, los obreros de la fábrica de Cádiz acordaron trabajar diariamente una hora extraordinaria en beneficio de una suscripción nacional a favor del Ejército (lbid., 28-X-1936). En diciembre de 1937, el consejo de la CAT comunicó al jefe de la fábrica de La Coruña uque a base de no interrumpir la normal producción actual, establezca media o una hora de jornada extraordinaria diaria, al efecto de la elaboración del donativo aludidon. Se hacía referencia a un envío de 162 fardos de tabaco, por orden de la Jefatura del Estado/Sección Donativos, para su elaboración y transformación en cigartillos. No se tiene constancia de que las operarias de La Coruña cobraran por ese trabajo, pero aun en ese caso lo que está claro es que la ampliación de la jornada laboral se les impuso sin que tuvieran opción a apelar y sin escuchar su opinión (ACAT/ZN, 28-XII-1937).

85 Con fecha del 29 septiembre de 1937, el consejo de administración de la CAT secibió una comunicación de la Representación del Estado autorizando a la fábrica de La Coruña a establecer dos turnos de trabajo intensivo de 6 horas, a base de percibir los mismos jornales y elevando los premios en un 33 por 100; la Compañia quedaba facultada para extender el mismo régimen a las fábricas que fuera necesario (ACAT/ZN, 10-X-1937). Otro oficio del 1 de junio de 1938, también de la Representación del Estado, daba traslado de la resolución adoptada por el Ministerio de Organización y Acción Sindical autorizando a las fábricas de las Rentas de Tabacos y Fósforos para trabajar todos los días festivos, excepto los domingos, mientras durasen las circunstancias de la guerra (Ibid., 10-VI-1938). El consejo de administración mantuvo la postura de que las horas comprendidas dentro de la jornada máxima legal trabajadas en días festivos debían ser abonadas sin recargo de horas extraordinarias (lbid., 20-X-1938). En cuanto a la sobreproducción, buena muestra de hasta donde se llegó fue que en una reunión del consejo fechada el 21 del mes de junio de 1938 la propia ejecutiva de la CAT reconocía que, a esas alturas, no parecía ya «aconsejable forzar aún más la producción que hoy se realiza con jornadas diarias de diez horas» (lbid., 21-VI-1938). Pata los traslados de obreros de la fábrica de Bilbao a otras, véase lbid., 21-X-1937, donde también se habla de traer operarias de otros lugares a la fábrica de San Sebastián. 
tabaco. En las fábricas donde contó con medios edificó su propia estructura sindical, sin que los responsables de la empresa opusieran la más mínima resistencia, limitándose a dejar hacer: en la de Gijón, por ejemplo, fue constituido el Sindicato de Tabacos de F.E.T. de las J.O.N.S. en noviembre de 1937; el consejo de la Compañía no hizo otra cosa que darse por enterado. En la de Logroño un grupo de varios oradores de la Oficina de Prensa y Propaganda pronunciaron varias conferencias en la primavera de 1938 explicando a los obreros "el sentido del Fuero del Trabajo». En todas las ocasiones se interrumpió el trabajo por espacio de media hora. Lo curioso del caso (pero comprensible por las circunstancias de guerra y represión) es que muchas veces, allí donde había habido una sólida tradición sindical de izquierdas, el encuadramiento de los obreros por los falangistas daba pie a un notable colaboracionismo, al menos por parte de algunos trabajadores. En la fábrica de La Coruña, durante 1938, hubo obreros que prestaron eservicios de 2a. línea» en la plaza a instancias de la Milicia de F.E.T. de las J.O.N.S de la localidad. En compensación, el jefe de la citada milicia gestionó ante la dirección de la fábrica que tales asalariados cobrasen íntegros sus jornales cuando se tuvieron que ausentar temporalmente del trabajo por aquel motivo ${ }^{86}$.

Pocas fueton las mejoras que obtuvieron los trabajadores en tiempo de guerra, y cuando se logró alguna hubo detrás una clata intencionalidad propagandística. La Caja de Ahorros de los empleados administrativos de la Arrendataria funcionó en la zona rebelde durante la guerra, pero con sus atribuciones muy mermadas al quedar en suspenso el abono de liquidaciones por fallecimiento $o$ por cese de prestación de servicios en la Compañía. Sólo en lo que se refiere a concesión de préstamos tuvo la Caja alguna resonancia. A finales de 1938, por otra parte, el Servicio Nacional de Timbre y Monopolios comunicó a la CAT que estaba obligada a establecer comedores en los recintos fabriles y en todos sus establecimientos permanentes, siempre que el número de los trabajadores empleados excediera de cincuenta. Por esas mismas fechas, el consejo de administración solicitó del Estado un crédito de 400.000 pesetas para la construcción de guarderías infantiles en las distintas fábricas ${ }^{87}$.

86 ACAT/ZN, 29-XI-1937 (Gijón), 10-V-1938 (Logroño), 10-VIII-1938 (La Coruña). Significativamente, en febrero de 1939, a instancias del gobernador civil de esta provincia, fueron designados diez obreros de La Coruña para prestar servicio «de Vigilancia y Policía» en Barcelona durante 45 días. El puesto de trabajo se les guardó, y los sueldos y gratificaciones fueron percibidos durante ese tiempo por sus familiares (lbid., 8-II-1939). Un año antes, en las actas del consejo de administración de la CAT se dejó constancia de la petición de un capataz de la fábrica de Bilbao, Restituto Ortiz, para que se le reservase su plaza hasta que pudiera incorporarse al trabajo, «por hallarse en la actualidad encuadrado en la Brigada de Investigación y Vigilancia de F.E.T. y de las Jons». El consejo accedí a lo solicitado (Ibid., 30-I-1938).

87 Para la Caja, ACAT/ZN, 30-IX-1937. Los comedores, en lbid., 30-IX-1938. Las guarderías, en $I b i d ., 29-X I-1938$. 
En orden a materias de previsión no hubo progreso alguno. Por el contrario, el engranaje previamente existente se tesintió. En algunas fábricas el paso a los «talleres auxiliares» —en concepto de semijubilación- de aquellos obreros y cigarreras carentes de capacidad para seguir trabajando por razones de edad o enfermedad, continuó funcionando durante la guerra. Pero no fue general su aplicación. Como tampoco el régimen de retiros que, tras muchas décadas demandándolo, fue establecido en vísperas de la Guerra Civil por una orden ministerial del 2 de julio de 1936. En esta cuestión, la Compañía actuó con absoluta discrecionalidad y según sus propias conveniencias, no dudando en suspender su aplicación con el argumento de que escaseaba el personal, aunque los afectados hubieran traspasado con creces la edad legal para dejar de trabajar. Unicamente al término de la guerra aceptó la Compañía restablecer el sistema de jubilaciones en su totalidad, haciendo para ello las oportunas gestiones ante las autoridades del nuevo régimen y presentando esa resolución como un logro, cuando en realidad recaía sobre la empresa gran parte de la responsabilidad en lo que no había sido sino una práctica suspensión del principio de jubilación durante el conflicto ${ }^{88}$.

Quienes sí vieron atendidas, al menos en parte, sus aspiraciones y derechos fueron aquellos empleados y trabajadores que desde el primer día se pusieron del lado de la rebelión, o que gozaban de una trayectoria inequívocamente derechista con anterioridad a ese estallido. A todos aquellos que tuvieron que prestar servicios en el Ejército o en las milicias voluntarias, en tanto que no percibieron ingresos en esos ámbitos, la Compañía les garantizó el abono íntegro de sus haberes. En mayo de 1937, el consejo de administración acordó dirigir una circular a las fábricas, depósitos y demás dependencias de la empresa ratificando esa decisión ${ }^{89}$. En cambio, el mero hecho de que a alguien le hubiera sorprendido la guerra en la zona leal al gobierno de la República le suponía, cuando los nacionales ocupaban su ciudad o cuando él mismo se pasaba de zona, la suspensión del cobro de los haberes que no hubiera percibido. Ese era el criterio de los responsables políticos y la Compañía no dudó en hacerlo suyo, pues era una forma de negar legitimidad a la gestión realizada en las fábricas tabaqueras mientras se hallaron subordinadas a las autoridades republicanas (o dicho en términos más precisos, a los sindicatos revolucionarios que habían puesto en práctica en ellas el «control obrero» y destituido a los representantes de la Compañía). Esa actitud respondía también a la desconfianza que a priori se manifestaba hacia los empleados y obreros que habían servido en territorio enemigo, hasta que no se demostrara fehacientemente su absoluta carencia de responsabilidades políticas y de antecedentes colaboracionistas ${ }^{90}$. Sólo hubo una

La resolución al respecto, en ACAT, 31-V-1939.

39 ACAT/ZN, 12-V-1937. También, lbid., 9-X-1936.

9 En marzo de 1938, por poner un ejemplo, se analizaron en el consejo de administración las solicitudes formuladas por el oficial administrativo, Ernesto Fuentes, y por el prácticante, Luis Rollán, para que les fueran abonados los haberes no percibidos durante el dominio «rojo» en la fábrica 
excepción a esa regla y con carácter muy restringido: en algunos casos la empresa abonó sueldos de empleados de las fábricas republicanas dejados en suspenso cuando ello se debió a represalias políticas, ya fuera por su significación derechista o por haber demostrado fidelidad inquebrantable a la Compañía en tales circunstancias ${ }^{11}$.

El personal adicto a la causa, que además no contara con antecedentes de izquierdismo en el períado previo a julio de 1936, tuvo el total apoyo de los responsables de la CAT, se le confiaron puestos de responsabilidad y se benefició de las oportunas recompensas. En este sentido, por ejemplo, es significativo que el cargo de inspector médico de fábricas - un cargo de gran responsabilidad a ojos de la empresa- lo ocupara un médico procedente de la de Madrid que se hallaba en "zona liberada», por darse "la circunstancia de ser el único de los médicos de aquella fábrica que no había ingresado en la Federación Tabaquera». Es ilustrativo, igualmente, que cuando en la dependencia de Gijón se pusieron de nuevo en marcha los trabajos, tras la ocupación de la ciudad por las tropas antirrepublicanas, fuera con 130 operarias que inmediatamente antes del estallido de la guerra habían estado afiliadas al antiguo Sindicato Católico"2 ${ }^{92}$ Como no podía ser menos, además, la Falange de aquella ciudad solicitó de la CAT que, cuando se reanudase la producción en todos los talleres, se tuviera en cuenta en primer lugar a los familiares de los mártires de la guerra. La empresa accedió gustosa porque esa venía siendo también su política desde el comienzo de la conflagración:

«Carta de la Jefatura de Falange Española Tradicionalista y de las Jons de Gijón, fecha del 21 del actual, solicitando la reanudación de los trabajos en todos los talleres, y se dé preferencia en los mismos a las viudas, hijas, madres o hermanas de asesinados por los rojos, indicando además que la organización local de Falange, tiene una lista de 50 personas que se hallan en las condiciones apuntadas y que confía sean colocadas. El Consejo acuerda informar a la Jefatura de Falange de Gijón que viene siendo norma invariable de la Presidencia, cuando ha habido

\footnotetext{
de Gijón. «El Consejo acordó denegar las solicitudes expresadas por exponer el Sr. representante del Estado que el criterio del poder público a este respecto es dejar estos pagos en suspenso por el momento" (ACAT/ZN, 11-IU-1938). Después del análisis de las actas del consejo de administración hassta el final de la guerra, no se tiene constancia de que se levantara la supensión de este pago y otros de similares caracceríscicas.

91 En una carta procedente de la fábrica de Santander fechada el 20 de diciembre de 1937, se daba cuenca de las instancias sobre abono de haberes presentadas por Lino Horna Varona y José Higuera, maquinistas de aquella fábrica que habían sido suspendidos de empleo y sueldo, por dos meses, «durante el dominio rojo por la Federación Tabaquera y el Consejo Obrerow. El consejo de administración acordó tealizar el pago requerido *teniendo en cuenta que ambos empleados han sido siempre modelo de adhesión a la Compañía y sus Jefes, dando a tal acuerdo carácter excepcional» (ACAT/ZN, 28-XII-1937).

92 El médico, en ACAT/ZN, 21-X-1937. De todas formas, incluso ni las citadas obreras católicas se libraron de pasar por la comisión que instruía los expedientes de depuración (ACAT/ZN, 19-X-1937).
} 
necesidad de admitir personal en Fábricas de las poblaciones liberadas, el atender preferentemente a los familiares de quienes han sufrido persecución o han sido víctimas de sus ideales antimarxistas, por ello cuando sea necesaria la admisión de nuevo personal en la Fábrica de Gijón, se tendrá en cuenta la gestión de la Jefatura aludida a base de que el personal reúna las condiciones reglamentarias que son ineludibles" $\$$ "

Cuando no hubo posibilidad de dar colocación a los familiares de las víctimas de la causa nacional, la Compañía ofreció repetidamente algún tipo de auxilio en concepto de «socorro extraordinario". La ejecutiva de la Arrendataria procuró siempre, en estos casos, aliviar la situación económica en que quedaban las familias golpeadas por "la barbarie marxista». Pero bien es cierto que llegó un momento en que se vio desbordada por los acontecimientos, sobre todo al término de la guerra, tal era el número de solicitudes de empleo presentadas por los ex combatientes. A esas alturas no quedó más remedio que restringir la contratación interponiendo los filtros necesarios: «en el sentido de que no ha de reservarse plaza alguna a los desmovilizados por el mero hecho de serlo». Claro que muchas de esas solicitudes encontraron la puerta abierta poco después, cuando los procesos de depuración instruidos en la postguerra dieron pie a numerosas expulsiones de hombres y mujeres con vinculaciones izquierdistas de las fábricas recién conquistadas. Al fin y al cabo, esa había sido la lógica que, sin ponerse de acuerdo, habían aplicado los dos bandos en la industria del tabaco de ambas zonas durante la guerra. Tal lógica — premiar al correligionario, y castigar al desafecto- - iba a continuar ahora con matemático, implacable y consciente cálculo. Ciertamente, por tanto, la guerra no terminó para los vencidos el 1 de abril de 1939. En el particular ámbito de la industria tabaquera, cabe añadir que la victoria franquista y los durísimos años que vinieron después enterraron para siempre la imagen de combatividad que sus trabajadoras y trabajadores (las míticas «cigarreras», en especial) habían levantado tras muchas décadas de rebeldía y protestas ${ }^{94}$.

93 ACAT/ZN, 28-XII-1937. Conforme a esa misma estrategia de recompensar a los obreros y empleados fieles, el consejo de la CAT aprobó financiar ocho casas para otros tantos crabajadores de la fábrica de Cádiz, cuando el gobernador civil de la provincia lo solicitó a instancias, nada más y nada menos, que «del Excmo. Sr. General Queipo de Llano» (ACAT/ZN, 1-V-1938).

9i Ejemplos de socorros extraordinarios a familiares de asesinados "por los rojos», en ACAT, 21-VI-1939. La cita sobre el filtro, en Ibid., 21-VI-1939, a propósito de una consulta formulada desde ta fábrica de Santander y el depósito de elaborados respeceo a si habían de reservarse algunas plazas a los desmovilizados. La depuración de postguerra, en REY Regullo (1998), pp. 99-109. 


\section{FUENTES Y BIBLIOGRAFIA}

\section{FUENTES PRIMARIAS}

Archivo del Congreso de los Diputados (Madrid)

- Sección General, leg. 460-14, legislatura 1921.

Archivo de Tabacalera (Madrid) ${ }^{* *}$

- Actas del Comité de Gerencia, 1936-1937 (ACG).

- Actas del Consejo de Administración de la CAT, 1916-1939 (ACAT).

Anuarios, libros y folletos

- COMPAÑía ARRENDATARIA DE TABACOS (1888): Reglamento orgánico de las fábricas, Madrid, Tipografía de Manuel G. Hernández.

- [CoMpaÑía ARRENDATARIA DE TABACOS] (1889-1936 y 1940-1963): Memoria(s) leida(s) en la Junta General de Accionistas de la Compañia Arrendataria de Tabacos el día..., Madrid.

- Compañía ARRENDaTARIA DE TABacos (1897): Reglamento del cuetpo de empleados técnicos y sus auxiliares aprobado por el Consejo de Administración en sesión de 3 de junio de 1897, Madrid, Imprenta de los Hijos de M. G. Hernández.

- Reglamento referente al personal obrero de las Fábricas de Tabacos, aprobado por Reales órdenes de 13 de diciembre de 1926 y 14 de enero de 1927, Madrid, 1927.

- SANTIAs, Alberto (1894-1946): Anuario Administrativo, Económico, Financiero y de la Renta de Tabacos de España, Madrid.

- SECRETARÍ DEL CONSEjO DE ADMINISTRACIÓN (1888): Memoria del sr. Subdirector, $D$. Amós Salvador presentada al Consejo de Administración en septiembre de 1888 y aprobada, s. l. [ejemplar manuscrito].

Prensa

- Federación Tabaquera Española. Revista Sindical Tabaquera. Madrid, 1936.

—Unión Tabacalera, órgano de la Federación Tabaquera Española, 1932-1935.

\section{FUENTES SECUNDARIAS}

\section{Libros y artículos}

- Alonso Alvarez, Luis (1994): «Crecimiento de la demanda, insuficiencia de la producción tradicional e industrialización del sector tabaquero en España, 1800-1935", en Jordi Nadal y Jordi Catalán (eds.): La cara oculta de la industrialización española. La modernización de los sectores no líderes (siglos XIX y XX), Madrid, Alianza, pp. 163-197.

- BAENA LUQUe, Eloísa (1993): Las cigarreras sevillanas. Un mito en declive (1887-1923), Málaga, Universidad de Málaga.

** Puntualmente se citan otras series documentales del archivo que se detallan a pie de página.

Hispania, LX/3, núm, 206 (2000) 1067-1126 
- Bricald, Josep M. (1986): «La economía española (1936-1939)», en Manuel Tuñón de Lara y otros: La Guerra Civil española 50 años después, Barcelona, Labor.

- CABRERA, Mercedes (1983): La patronal ante la II República. Organizaciones y estrategia, Madrid, Siglo XXI.

- CANDEla Soto, Paloma (1993-1994): «Trabajo y organización en la industria del tabaco: las cigarreras madrileñas, 1890-1920», Sociología del Trabajo, $n^{\circ} 20$, pp. 91-115.

- CANDEla SOTO (1995): «Condiciones de vida (y trabajo) de las cigarreras madrileñas a comienzos del siglo XX", en S. Castillo (ed.): El trabajo a través de la bistoria, Madrid, Asociación de Historia Social-UGT, pp. 383-391.

- CANDELA SOTO (1997): Cigarreras madrileñar: trabajo y vida (1888-1927), Madrid, Tecnos.

- CAPEL MARTíneZ, Rosa Matía (1982): El trabajo y la educación de la mujer en España (1900-1930), Madrid, Ministerio de Cultura.

- COMín COMín, Francisco y MARTín ACEÑA, Pablo (1999): Tabacalera y el estanco del tabaco en España, 1636-1998, Madrid, Fundación Tabacalera.

- GÁlvez MUÑOZ, Lina (1997): La mecanización en la Fábrica de Tabacos de Sevilla bajo la gestión de la Compaña Arrendataria de Tabacos (1887-1945). Documento de Trabajo, $\mathrm{n}^{\circ}$ 9.709, Madrid, Fundación Empresa Pública.

- GonzÁlez CAlleja, Eduardo y ReY REgulloo, Fernando del (1995): La defensa armada contra la revolución. Una bistoria de las 'guardias civicas' en la España del siglo XX, Madrid, CSIC.

- LeRma Bragado, C., Callejo SaIz, M. y BILBaO Martínez, S. (1991): Diez años en la bistoria de la Fábrica de cigarros de Santander, 1930-1940: una década de transformaciones e las relaciones laborales $y$ de praducción, Bilbao, edición de los autores mecanografiada.

- MORANGE, Claude (1980): «De 'manola' a obrera. (La revuelta de las cigarreras de Madrid en 1830. Notas sobre un conflicto de trabajo)", Estudios de Historia Social, núms. 12-13, enero-junio, pp. 307-321.

- NúÑEZ PÉREZ, Gloria (1989): Las trabajadoras en la Segunda República. Un estudio sabre la actividad económica extradoméstica (1931-1936), Madrid, Ministerio de Trabajo y Seguridad Social.

— PÉrez Ledesma, Manuel (1990): Estabilidad y conflicto social. España, de los íberos al 14$D$, Madrid, Nerea.

- PÉReZ VIDAL, José (1959): España en la bistoria del tabaco, Madrid, Centro de Estudios de Etnología Peninsular.

- ReY Regullio, Fernando del (1989-1990): «La polémica sobre el control obrero. Los origenes en España», Sociología del Trabajo, $\mathrm{n}^{\circ}$ 8, pp. 135-165.

- ReY Reguillo, Fernando del (1992): Propietarios y patronos. La politica de las organizaciones económitas en la España de la Restauración (1914-1923), Madrid, Ministerio de Trabajo y Seguridad Social.

- REY Reguillo, Fernando del (1998): Relaciones laborales en la industria tabaquera española (1887-1995). Documento de Trabajo, $\mathrm{n}^{\circ} 9811$, Madrid, Fundación Empresa Pública.

- REY Regunlo, Fernando del y PéreZ Garzón, Juan Sisinio (1994): «Conflictos y protestas. De la ciudad liberal a la ciudad democrática, 1808-1978", en Francesc Bonamusa y Joan Serrallonga (eds.): La sociedad urbana, $2^{\circ}$ Congreso de la Asociación de Histotia Contemporánea, Barcelona, Asociación de Historia Contemporánea, pp. 257-321.

- Romero Masía, Ana (1997): A fábrica de tabacos da Palloza, s.l., U.G.T. Galicia/ Fundación Luis Tilve. 
- Romero Masía, Ana (2000): Severino Cbacón: un lider sindical no mundo do tabaco, Universidade Da Coruña (tesis doctoral cortesia de la autora).

- Torres Villanueva, Eugenio (1998): La fundación de la Compañía Amendataria de Tabacos. Documento de Trabajo, n 9808 , Madrid, Fundación Empresa Pública.

- Valdés Chapulí, Caridad (1990): La Fábrica de Tabacos de Alicante, Alicante, Caja de Ahorros del Mediterráneo.

- VALLEJo FerNÁNDEZ, Sergio (1986): «Las cigarreras de la Fábrica Nacional de Tabacos de Madrid", en L. E. Otero Carvajal y A. Bahamonde (eds.): Madrid en la sociedad del siglo XIX, vol. 2, Madrid, Comunidad de Madrid-Revista Alfoz, pp. 135-149.

Hispania, LX/3, núm. 206 (2000) 1067-\$126 